\title{
Pattern of sedimentary infilling of fossil mammal traps formed in pseudokarst at Cerro de los Batallones, Madrid Basin, central Spain
}

\author{
JOṤ P. CALVO*, MANUEL POZO†, PABLO G. SILVA $\ddagger$ and JORGE MORALES§
}

*Department of Petrology and Geochemistry, Universidad Complutense, c/Jose Antonio Novais 2, 28040 Madrid, Spain (E-mail:jpcalvo@geo.ucm.es)

†Department of Geology and Geochemistry, Faculty of Sciences, Universidad Autonoma de Madrid, 28049 Madrid, Spain

‡Department of Geology, Universidad de Salamanca, Escuela Politecnica Superior de Avila, 05003 Avila, Spain

$\S$ Department of Palaeobiology, Museo Nacional de Ciencias Naturales-CSIC, c/José Gutierrez Abascal 2, 28003 Madrid, Spain

\begin{abstract}
Fossil mammal sites of late Miocene age ( $\mathrm{ca} 9 \mathrm{Ma}$ ) occur in hourglassshaped, non-interconnected cavities up to $15 \mathrm{~m}$ deep, hosted in mudstone (mostly sepiolite), chert and carbonate bedrock in Cerro de los Batallones. This paper provides a model for the sedimentary infilling of the cavities, which functioned as traps for vertebrate faunas and contain one of the richest and best preserved Neogene mammal assemblages of the Iberian Peninsula. Generation of the mammal-bearing cavities started with the solution of underlying evaporites, which resulted in fissures that were subsequently enlarged by subsurface piping, a process rarely preserved in the ancient sedimentary record. The system of subterranean cavities evolved into a pseudokarst landscape, resulting in doline-like shafts reaching the ancient land surface. The sedimentary infilling of the cavities comprises both clastic and carbonate lithofacies that were investigated by outcrop observation, standard and scanning electron microscope petrography, mineralogical analysis, and stable isotope geochemistry. Gravel and breccia talus deposits, clast and mud-supported gravel, pebbly sandstone and mudstone are common detrital infill deposits mostly derived by overflow erosion of bedrock. The deposits containing the mammal bones are marls, and occur both in subsurface cavities and doline-like depressions. In the underground cavities, marlstone was mainly of clastic origin and accumulated in ponds scattered over the floor of the cavity. In contrast, marlstone deposits in the surface dolines formed mostly as a result of biochemical carbonate deposition in small shallow lakes subjected to fluctuation of the water level. The $d^{18} \mathrm{O}$ and $\mathrm{d}^{13} \mathrm{C}$ carbonate values indicate different origins for the two kinds of marls. During the final phases of pipe infill the doline marlstone sealed the mammal sites, usually off-lapping the adjacent bedrock.
\end{abstract}

Keywords Continental sediments, mammal sites, Miocene, piping, pseudokarst. 


\section{INTRODUCTION}

Fossil mammal sites occur in a variety of continental sedimentary facies, including alluvial fan, fluvial, lake, cave, spring deposits and other depositional environments (Behrensmeyer, 1991). Commonly, accumulations of mammal remains occur in stratified formations, although mammal sites hosted in laterally discontinuous, non-stratified to roughly bedded deposits characteristic of traps are not unusual. Moreover, trap mammal sites often contain faunal assemblages that are remarkable because of their quality of preservation and singularity, which is the case for many mammal sites found in former ponds, karstic cavities or other kind of clefts, shafts and fissures (Laury, 1980; Simms, 1994; MuñozDuran \& Van Valkenburgh, 2006; Reed, 2006).

This article describes and interprets the sediments filling fossil mammal-bearing cavities in Cerro de los Batallones, a structural butte developed by differential erosion of Neogene sedimentary formations in the north-western sector of the Cenozoic Madrid Basin, central Spain (Fig. 1). The Cerro de los Batallones mammal sites contain one of the richest and best preserved Neogene mammal assemblages of the Iberian Peninsula (Morales et al., 2008). Nine distinct mammal sites of late Miocene age ( $c a$ $9 \mathrm{Ma}$ ) containing abundant, well-preserved fossil vertebrate remains have been found in the upper part of a sub-horizontal succession of continental strata where sepiolite deposits have been mined since 1980. The first fossil mammal site was found in 1991 (Morales et al., 1992). Based both on the geometry of the sites, which occur as laterally disconnected patches in nonkarstic bedrock, and on the characteristics of the vertebrate assemblages, the mammal sites have been interpreted as traps (Morales et al., 2000). The objective of this study was to analyse the sedimentary deposits of the cavities where the mammal sites are located and to provide a model for the processes of sedimentary infilling associated with the accumulation of the mammal remains. The work provides a case study on

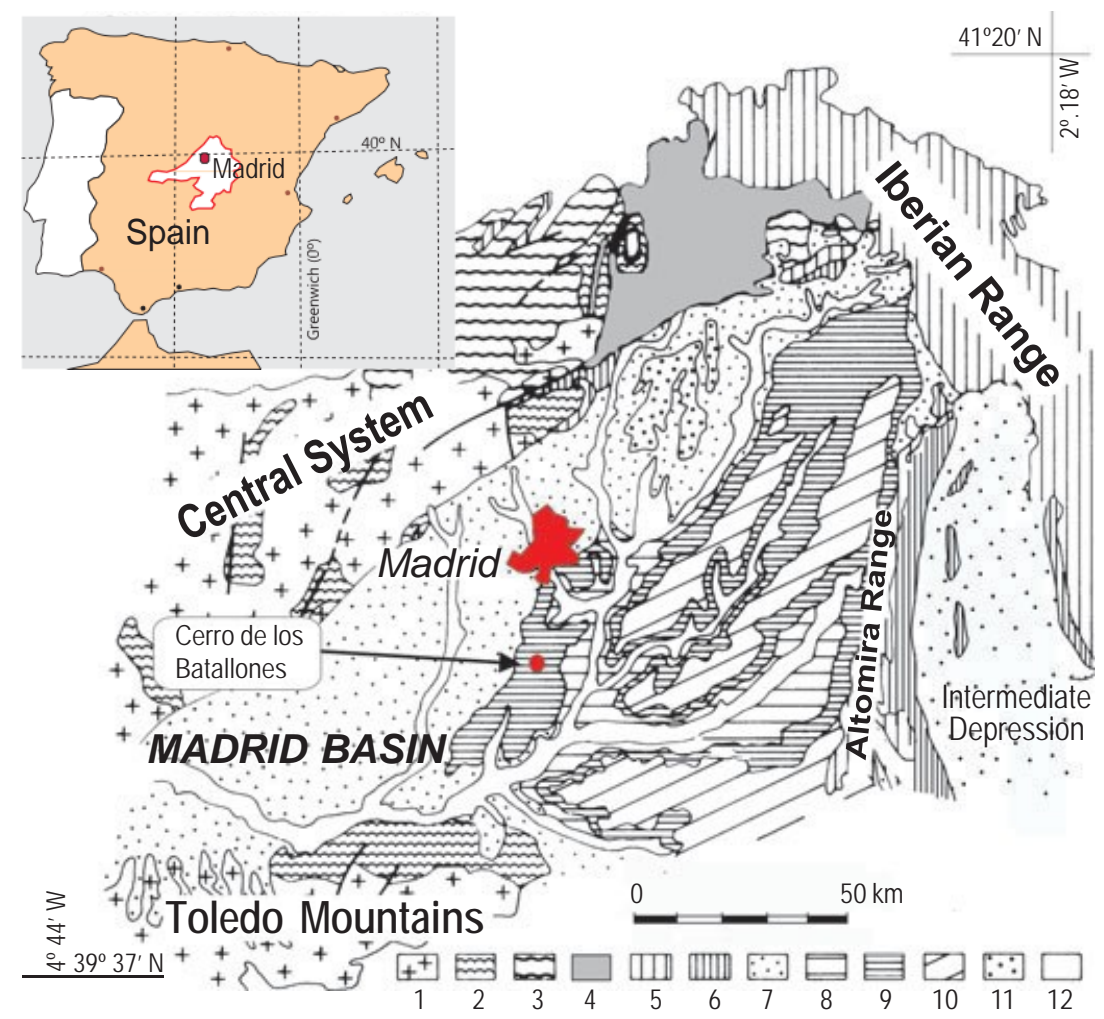

Fig. 1. Location of Cerro de los Batallones in the Tertiary Madrid Basin. Palaeozoic Basement: (1) granite and granitoids; (2) high-grade metamorphic rocks; (3) medium-grade metamorphic rocks; (4) low-grade metamorphic rocks. Mesozoic cover: (5) Cretaceous and Jurassic carbonate rocks. Cenozoic: (6) Palaeogene detrital and gypsum rocks; (7) Neogene arkosic materials; (8) Miocene Lower Unit; (9) Miocene Intermediate Unit; (10) Miocene Upper Unit; (11) Pliocene; (12) Recent sediments. Insert upper left shows location of the Madrid Basin (contoured in red) in the central part of the Iberian Peninsula. 
the formation of cavity systems and their related deposits in a pseudokarst context and improves current understanding of the depositional processes resulting in vertebrate remains accumulating in traps.

\section{GEOLOGICAL SETTING}

Cerro de los Batallones is one of a number of structural buttes south of the city of Madrid (Fig. 1). The buttes were carved from subhorizontal Miocene continental formations that comprise the uppermost part of the sedimentary sequence that filled the Tertiary Madrid Basin (Calvo et al., 1994; Alonso-Zarza et al., 2004). The basin formed as a result of intense Cenozoic Alpine deformation within the Iberian microplate driven by the Africa-Eurasia collision (De Vicente et al., 2011). During most of the Neogene, the basin was occupied by lacustrine and palustrine systems fringed by alluvial fan and fluvial distributary facies forming a centripetal drainage system (Calvo et al., 1995a). This sedimentary pattern, characteristic of endorheic geomorphological settings, changed to an exorheic regime during the late Miocene to Pliocene, a common feature in many Cenozoic Iberian basins (Calvo et al., 1993; Calvo, 2004; De Vicente et al., 2011).

The Neogene succession of the Madrid Basin has been divided into three main stratigraphic units of Miocene age, overlain by a relatively thin and discontinuous Pliocene sedimentary sequence (Alonso-Zarza \& Calvo, 2002) (Fig. 2). The boundaries between stratigraphic units are marked by palaeokarstic surfaces and/or minor

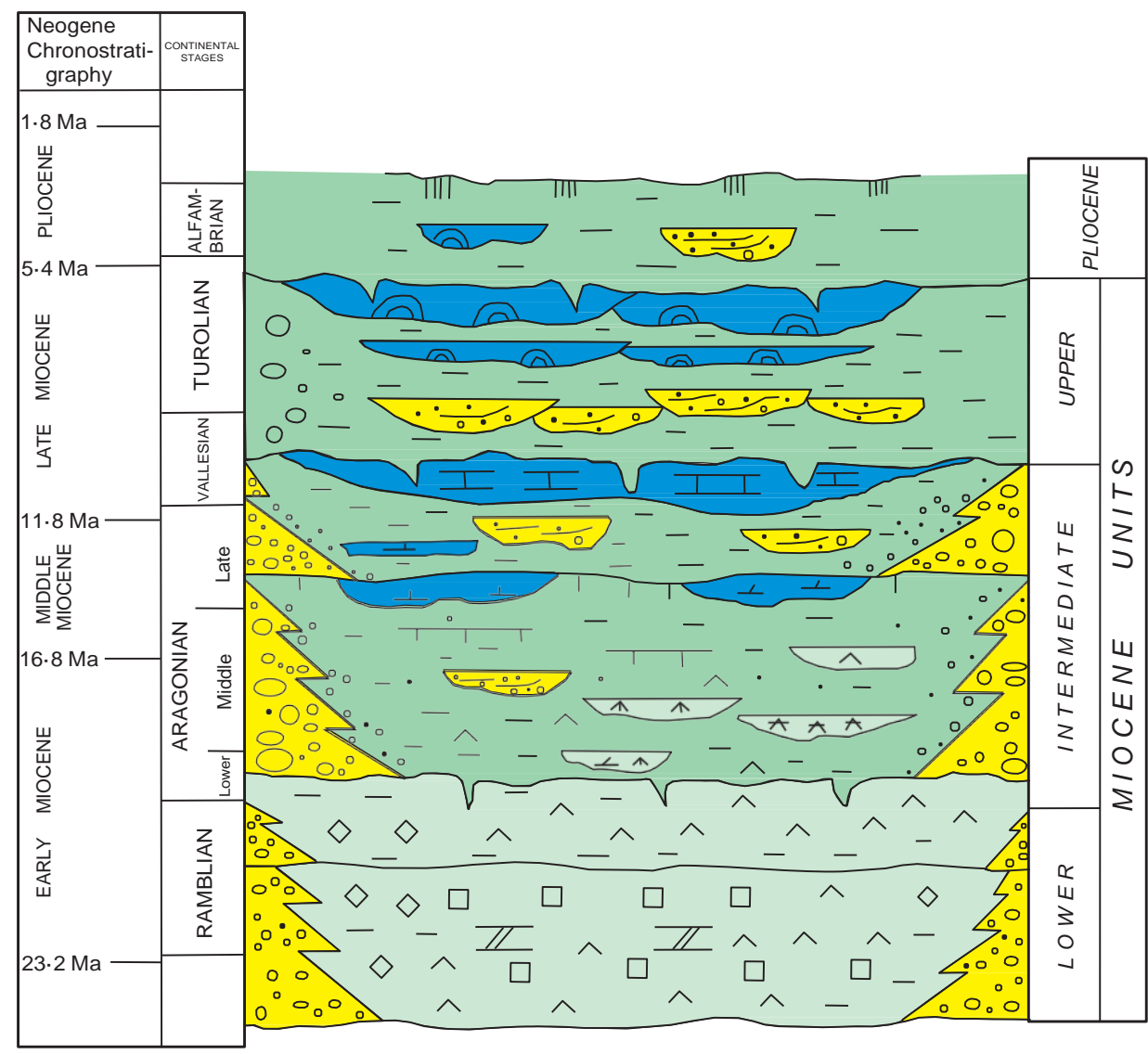

LEGEND

\begin{tabular}{|c|c|c|c|c|c|c|}
\hline 0.0 & Alluvial fan deposits & \begin{tabular}{|l|l|}
$T$ \\
\end{tabular} & Carbonate palaeosols & $\begin{array}{l}\text { II Lake carbonates } \\
\perp \perp \text { and carbonate ponds }\end{array}$ & $\square$ & Halite $\mathbb{I}$ Magnesite \\
\hline 응 & Gravel and sandstone channels & $\pi$ & Laminar calcretes & 入 Lake evaporites & $\diamond$ & Glauberite/Thenardite \\
\hline$=$ & $\begin{array}{l}\text { Alluvial (mudflat and floodplain) } \\
\text { mudstone }\end{array}$ & ค & $\begin{array}{l}\text { Carbonate fluviolacustrine } \\
\text { deposits }\end{array}$ & A Detrital/bioturbated gypsum & $\sqrt{ }$ & Palaeokarst \\
\hline
\end{tabular}

Fig. 2. Neogene stratigraphy of the Madrid Basin (modified from Alonso-Zarza \& Calvo, 2002). Asterisk indicates the stratigraphic location of Cerro de los Batallones palaeontological site. 
angular disconformities (Calvo et al., 1994; Cañaveras et al., 1996; Rodriguez-Aranda et al., 2002; Alonso-Zarza et al., 2004). The Lower Unit of Miocene age, spanning the Ramblian to early Aragonian ( $c a 25$ to $19 \mathrm{Ma}$ ), consists of up to $500 \mathrm{~m}$ of continental evaporite rocks (gypsum, anhydrite, halite and Na-sulphate) at the centre of the basin (Ordoñez \& Garcia del Cura, 1994). The Intermediate Miocene Unit (lower Aragonian to lower Vallesian; $c a 19$ to $10 \mathrm{Ma}$ ) is up to $200 \mathrm{~m}$ thick and consists of detrital gypsum, magnesian clay, marlstone, dolomite and limestone (Calvo et al., 1995a). The Upper Unit of Miocene age spans the late Vallesian to Turolian (ca 10 to $5 \mathrm{Ma}$ ) and is composed of fluvial terrigenous deposits overlain by freshwater lake carbonate rocks that occur mainly in the eastern and central parts of the basin, but are thin or even absent in the western sector of the Madrid Basin (Fig. 1).

Cerro de los Batallones represents a fine example of a structural butte preserved in the watershed of two major Quaternary fluvial lines related to the Tagus River in the Madrid Basin (Silva et al., 2012). Preservation of the morpho- logy of the buttes was strongly conditioned by the occurrence of chert horizons at several levels within the upper portion of the Intermediate Unit of the Miocene. These chert horizons formed mainly by early diagenetic replacement of calcareous and/or mudstone deposits (Bustillo \& Bustillo, 2000; Bustillo \& Alonso-Zarza, 2007).

Cerro de los Batallones is about $40 \mathrm{~m}$ high (the summit is $704 \mathrm{~m}$ above sea-level) and rises from a low-relief watershed area formed of flat lying mudstone and carbonate deposits that, in turn, overlie the gypsum facies of the Lower Unit of Miocene age. The uppermost part of the gypsum deposits can be mapped regionally on a surface about $600 \mathrm{~m}$ above sea-level. The lithostratigraphic sequence of Cerro de los Batallones is composed mainly of sub-horizontally bedded mudstone, calcareous and minor sandstone deposits (Fig. 3). Cerro de los Batallones occurs on the western limb of a large but gentle synform structure of karstic origin, regionally known as Los Gozquez-Valle de las Cuevas syncline (Silva et al., 1988). The sedimentary deposits that form the butte dip gently (10 to $12^{\circ}$ maximum) towards the syncline axis that

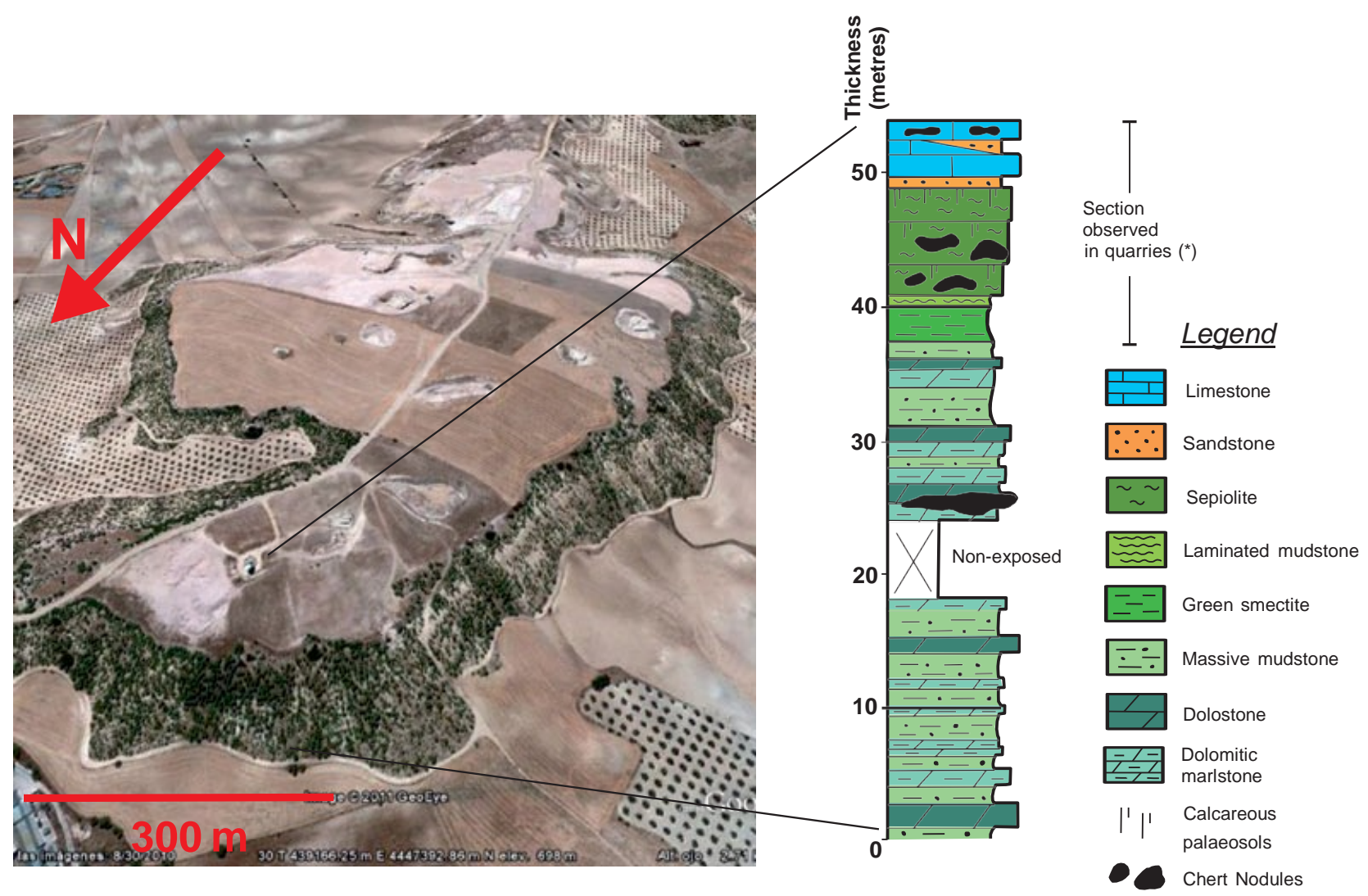

Fig. 3. Aerial view of Cerro de los Batallones. Log at the right of the image shows the general lithostratigraphy of the deposits that form the butte. 


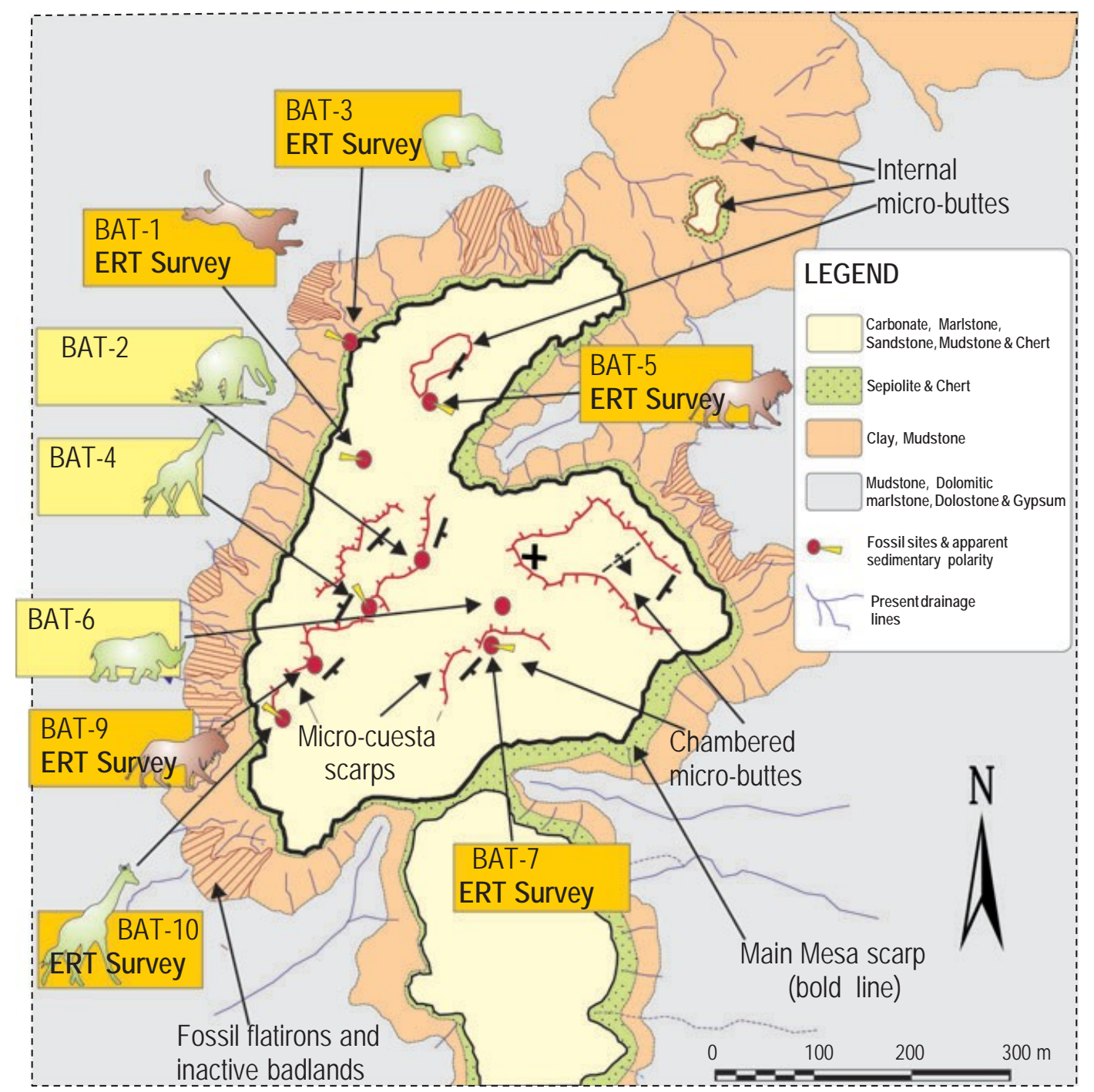

Fig. 4. Geological sketch of Cerro de los Batallones showing the main structural and geomorphological features observed in the area and the location of the fossil mammal sites. ERT = Electric Resistivity Tomography.

trends ESE (Fig. 4). The uppermost part of the sedimentary sequence is composed of up to $17 \mathrm{~m}$ of mudstone, chert and limestone that can be grouped into three main units (Pozo et al., 2004; Galan \& Pozo, 2011) (Figs 5 and 6).

No fossil remains were found in the abovedescribed sedimentary sequence so they cannot be dated by biochronology. However, the lithologies and facies associations of the deposits from Cerro de los Batallones clearly correlate with the top of the Intermediate Unit of Miocene age (Fig. 2) (Alonso-Zarza \& Calvo, 2002). Moreover, the sub-horizontal arrangement of the beds allows correlation with other structural buttes distributed in the vicinity of the city of Madrid where palaeontological information clearly indi- cates a middle to late Aragonian age for similar sedimentary sequences forming the upper part of the buttes (Morales et al., 2000).

Nine fossil mammal sites have been found so far in Cerro de los Batallones (Fig. 4). The sites occupy non-interconnected irregular cavities up to $15 \mathrm{~m}$ deep and are less than $10 \mathrm{~m}$ in diameter; they contain rich and well-preserved fossil faunas. Carnivore and herbivore fossils belonging to a large variety of mammalian taxa are abundant but teleostean, lissamphibian, squamate, chelonians and bird elements also occur (Morales et al., 2004; Domingo et al., 2011). Small and large faunal remains indicate a late Vallesian age ( ca $9 \mathrm{Ma}$; early late Miocene) for all the sites. Moreover, evidence furnished from 


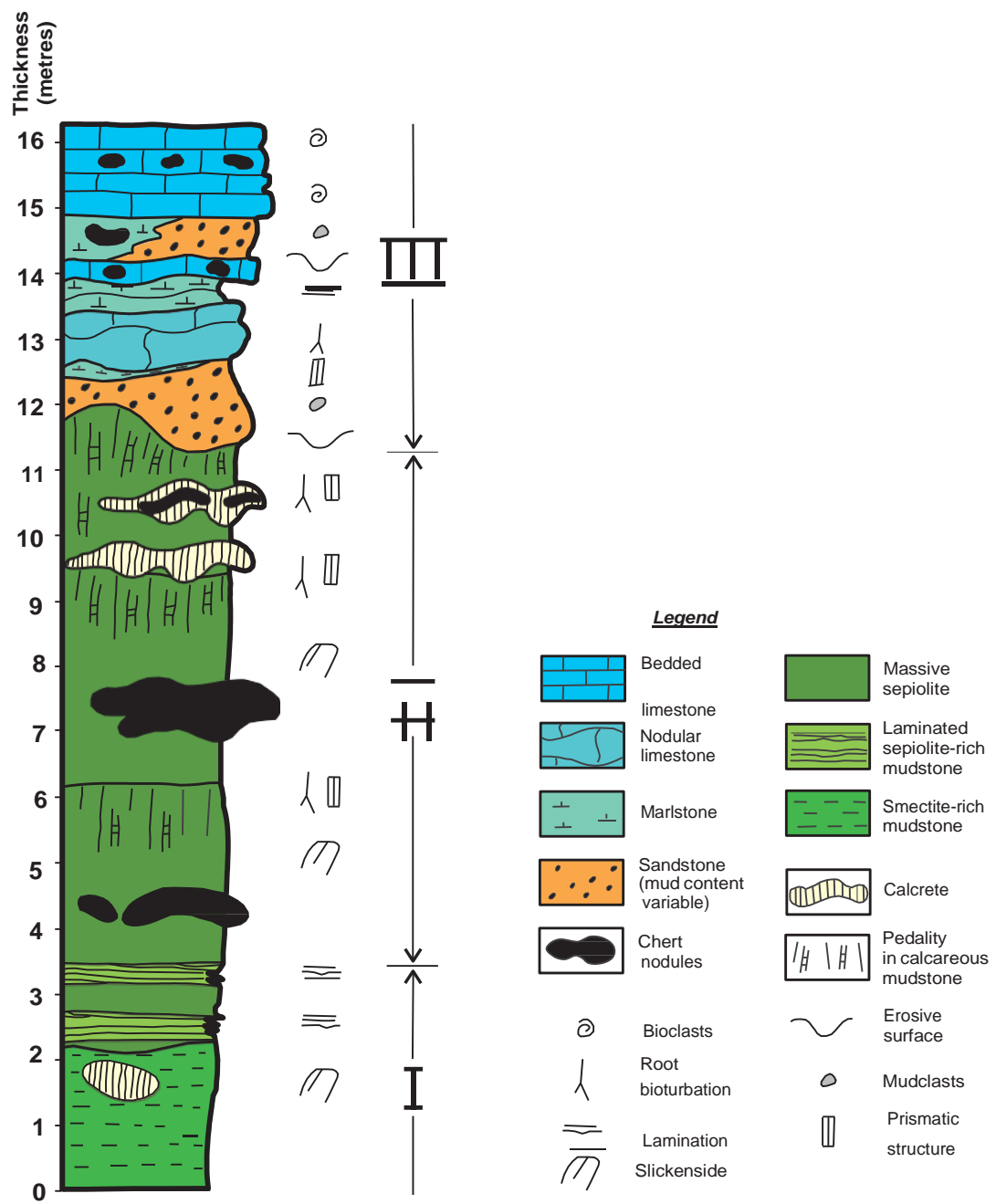

Fig. 5. Lithostratigraphic log of the Miocene sedimentary deposits forming the uppermost part of Cerro de los Batallones (modified from Galan \& Pozo, 2011).

the study of rodents indicates that there are slight age disparities amongst the different sites (Lopez-Antoñanzas et al., 2010).

\section{MATERIALS AND METHODS}

In all mammal sites, at least one section was studied and sampled for facies analysis. Some fossil mammal sites were large enough to allow observations in more than one section, so that geometric lateral correlation among different deposits could be established. A total of 155 samples were collected from the studied sections. In addition to the deposits filling the cavities, the geology of the bedrock was examined. More than 80 samples were collected from the three sedimentary units distinguished in the stratigraphic succession of Cerro de los Batall- ones. The petrography and mineralogy of the bedrock samples has already been published by Pozo et al. (2004) and Galan \& Pozo (2011).

A total of 125 samples were analysed by standard petrographic techniques. Some of the samples required consolidation before thinsections could be made. Alizarin red S stain of thin sections (Lindholm \& Finkelman, 1972) posed some problems for petrographic differentiation of clay-rich marlstone. Selected samples were examined under scanning electron microscopy (Philips SEM XL-30, FEI, Eindhoven, The Netherlands) after coating with gold in a sputtering chamber.

Mineralogical analysis of 148 samples was carried out by means of X-ray diffraction (XRD) using a Siemens D-5000 (Siemens AG, Gerätewerk - Karlsruhe, Germany) with a scanning speed of $1^{\circ} 2 h \mathrm{~min}^{-1}$ and $\mathrm{Cu}-\mathrm{Ka}$ radiation 


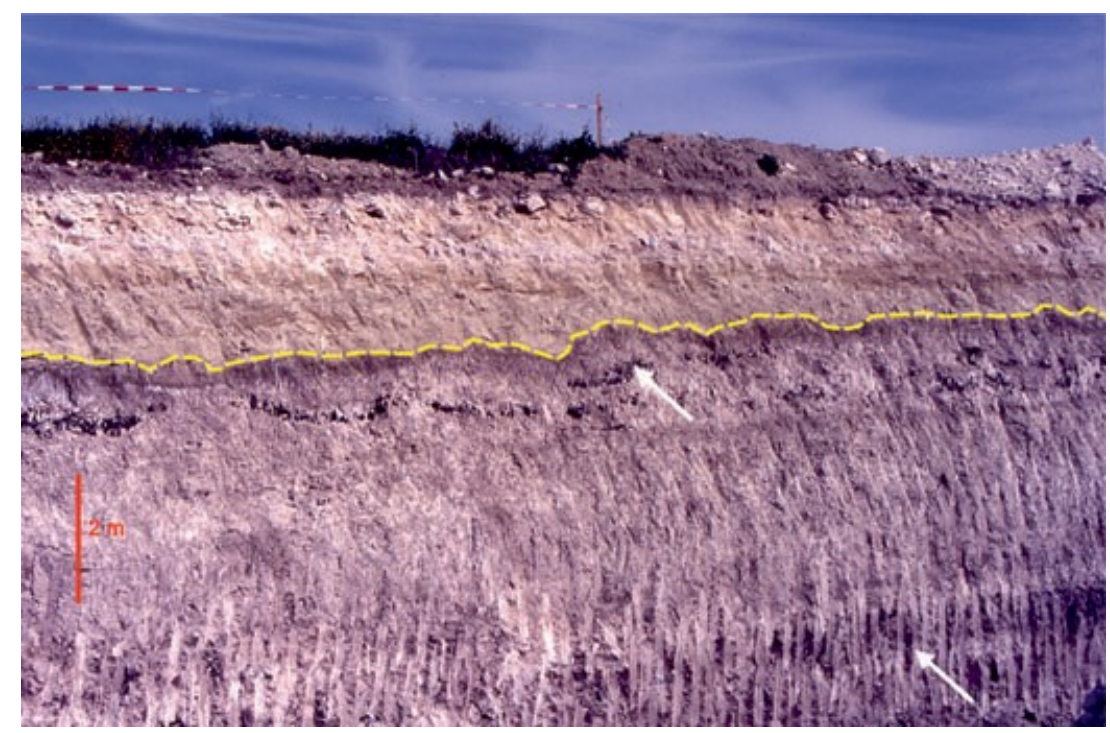

Fig. 6. View of the upper part of the stratigraphic succession of Cerro de los Batallones. The boundary between Units II and III is marked by a gilgai ‘mukkara’ (yellow dashed line) indicative of a palaeosol profile (Paton, 1974; Ahmad, 1996). Unit II comprises mainly sepiolite-rich mudstone containing chert nodules (arrowed); the overlying yellowish-whitish deposits correspond to detrital and carbonate sediments of Unit III.

(40 kV, $20 \mathrm{~mA})$. The XRD studies were carried out both on randomly oriented samples (bulk sample) and on selected clay fraction samples $(<2 \mathrm{Im})$. Powdered $(<63 \mathrm{Im})$ whole-rock samples were scanned from 2 to $65^{\circ} 2 h$. Clay fraction samples were prepared from cation-saturated, ultrasonic-treated suspensions oriented on glass slides. Identification of the clay fraction minerals was carried out on oriented $\mathrm{Mg}^{2+}$-saturated samples with ethylene glycol solvation, and also after heating at $550^{\circ} \mathrm{C}$ following $\mathrm{K}^{+}$saturation. Quantitative estimation of the mineral content was carried out using the intensity factors calculated by Schultz (1964) and Van der Marel (1966).

For stable isotopic analysis, 66 carbonate samples from the cavity fill and 53 carbonate samples from the bedrock were ground to pass through a $100 \mathrm{~lm}$ sieve and saved for analysis. The measurements were performed at the laboratories of the Interdepartmental Research Service (SIDI) of the Universidad Autonoma de Madrid. Carbon dioxide was evolved from each sample at $25^{\circ} \mathrm{C}$ using $100 \% \mathrm{H}_{3} \mathrm{PO}_{4}$. As determined by XRD, all samples for stable isotope analysis consisted of calcite without evidence of dolomite so that only the gas evolved in the first hour was considered. All samples were prepared and analysed at least in duplicate. The analytical precision is generally $\pm 0 \cdot 10 \%$ for carbon and $\pm 0 \cdot 15 \%$ for oxygen. Both oxygen and carbon values were initially reported in $\mathrm{d}$ permil relative to Vienna-Pee Dee Belemnite (VPDB).
The subsurface geometry of the unexcavated cavities was provided by electrical imaging techniques (Van Schoor, 2004; Kaufman et al., 2012) refined throughout successive Electric Resistivity Tomography (ERT) surveys (Fig. 4). In most of the investigated sites, breakdown and/or sharp lateral discontinuities of intervening chert horizons resulted in clear resistivity contrasts outlining the geometry of the subsurface cavities and their location (Fig. 7A). The ERT profiles were obtained by means of a multichannel (10) IRIS SYSCAL Pro resistivimeter (IRIS Instruments, Orlé ans, France) with different electrode spacing of 1 to $3 \mathrm{~m}$ and different multi-electrode arrangements (pole-pole, dipole-dipole and wenner).

\section{RESULTS AND INTERPRETATIONS}

A sketch showing the location and geometries of the cavities with the fossil mammal sites, either directly observed in outcrops and/or inferred from ERT profiles, is presented in Fig. 8. As observed in BAT-1 and BAT- 3 mammal sites, the lowermost parts of the cavities are directly on the magnesian smectite-rich mudstone from Unit I. The dimensions of the cavities are varied, with a maximum extent of about $100 \mathrm{~m}^{2}$ in the lower part of BAT-1. In most cases, the lower cavities continue upwards into subvertical pipes a few metres in diameter that are, in turn, connected with upper doline-like depressions. 

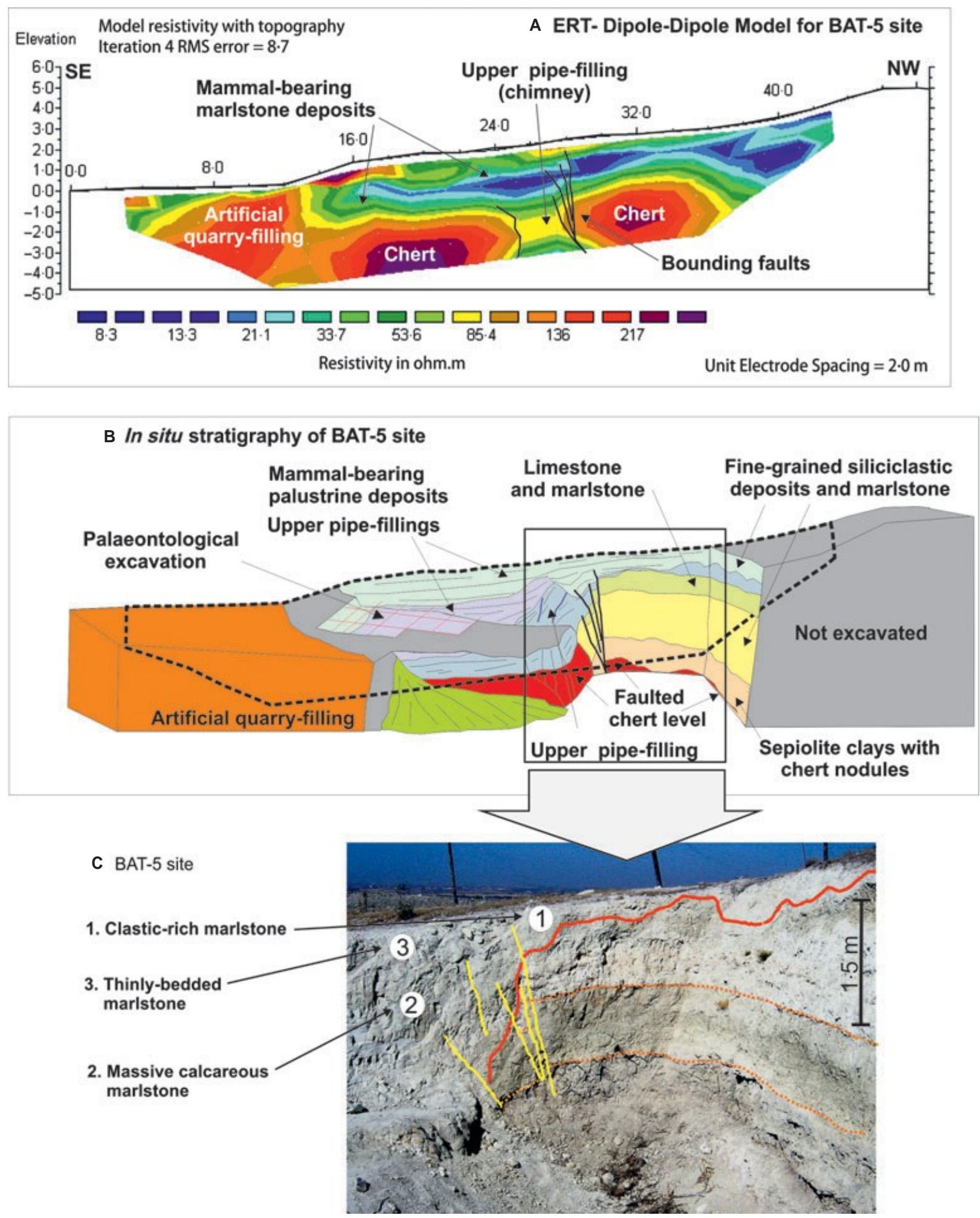

Fig. 7. (A) ERT 2D inverse model of the BAT-5 mammal site (2 m spacing Pole - Pole array) illustrating the distribution of resistivity anomalies detected at near-surface levels in the upper part of Cerro de los Batallones. Higher resistivity values correspond to resistant chert horizons. (B) Block diagram of the interpreted geological model based on both in situ stratigraphy and ERT data in BAT-5. (C) Fragile deformational pattern observed in bedrock and sedimentary infill of BAT-5. 


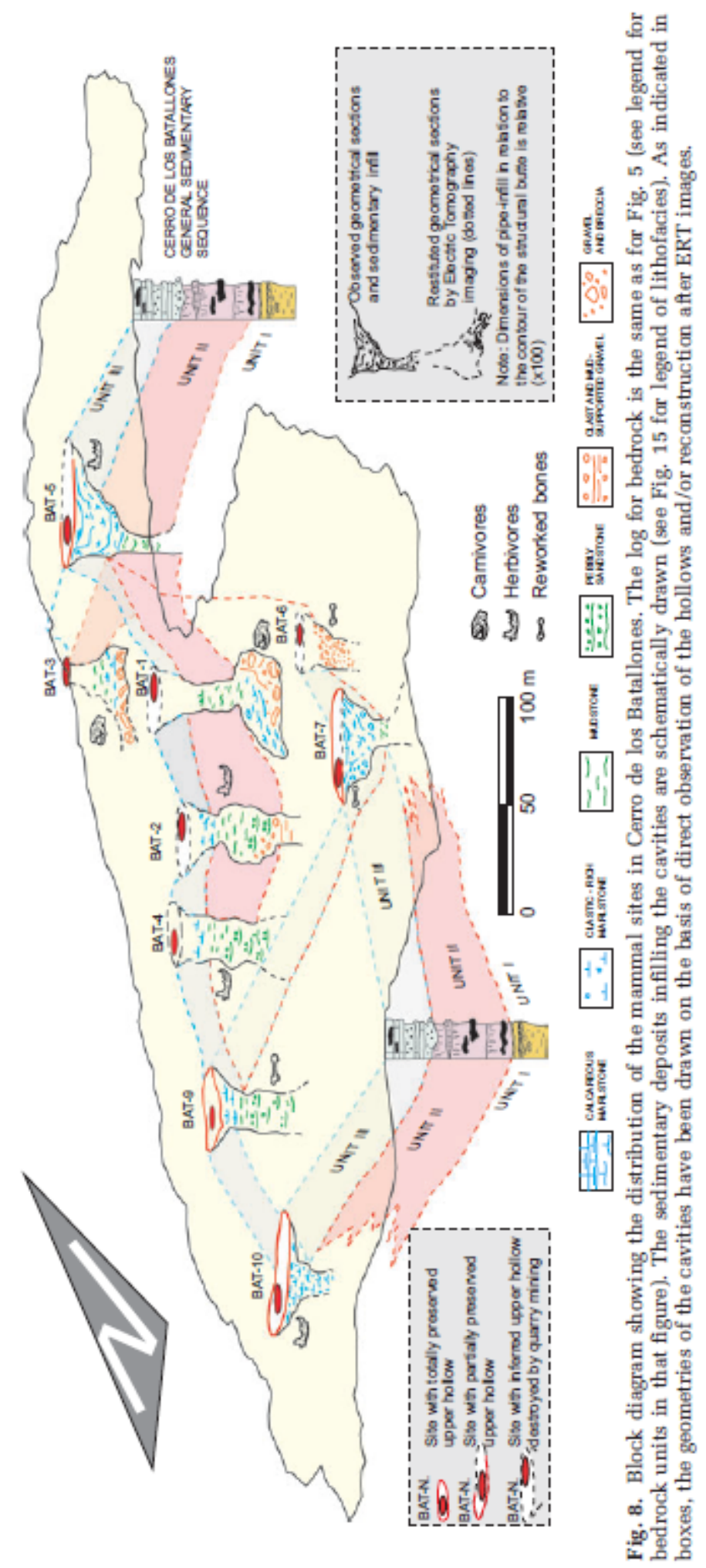



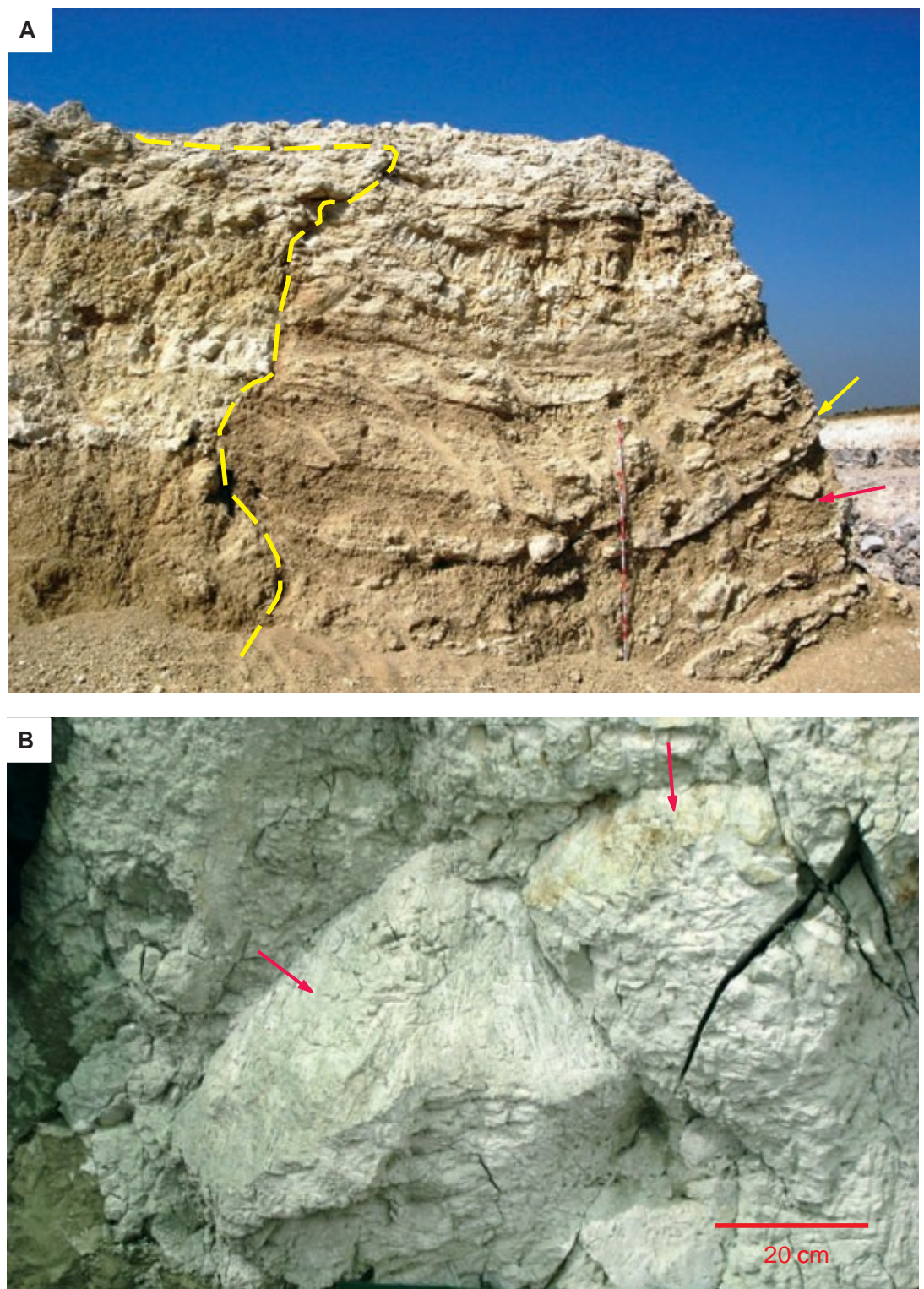

Fig. 9. (A) Front view of the BAT-9 mammal site; a sequence up to $4.5 \mathrm{~m}$ thick of clastic and calcareous marlstone deposits which filled a $7 \mathrm{~m}$ wide cavity encased in horizontally bedded sediments from Units II and III (yellow dashed line marks the boundary between bedrock and sedimentary infill of the cavity). Note that the infilling deposits are slightly folded; arrows at right of the image indicate beds dipping towards the central part of the cavity as well as the occurrence of crudely stratified, mud-supported gravel deposits derived from the right side of the cavity; $2 \mathrm{~m}$ stick for scale. (B) Prominent slickenside surfaces (arrowed) developed in calcareous marlstone deposits of BAT-5.

Where preserved, the upper parts of the pipes display cup-like geometry (Fig. 8). The resulting geometry of the cavities is a bell-like hourglass so that a general pattern of subterranean chambers or cavities passing upwards into doline-like depressions can be depicted.

The interpreted geological models from electrical anomalies detected in the ERT profiles (Fig. 7A) provide a more precise picture of the subsurface two-dimensional geometries for indi- vidual sites (Fig. 7B). Deeper penetrating ERT profiles provided evidence for underlying faults and bending structures matching the rather complex faulting and folding meso-scale to microscale pattern observed in the upper sections of the cavity walls (Fig. 7C). The recorded subsurface pattern is indicative of local deformation of the fragile sedimentary sequence of Cerro de los Batallones that extends downwards into the Intermediate Unit of Miocene age suggesting 
Table 1. Summary of main sedimentary features, textures and components of the main lithofacies recognized in cavities bearing fossil mammals in Cerro de los Batallones and their interpretation.

\begin{tabular}{|c|c|c|c|c|}
\hline Lithofacies & Sedimentary features & Texture/fabric & Components & Interpretation \\
\hline $\begin{array}{l}\text { Gravel and } \\
\text { breccia }\end{array}$ & $\begin{array}{l}\text { Poorly stratified, steeply dipping, } \\
\text { coarse-grained deposits. Local } \\
\text { soft-sediment deformation }\end{array}$ & $\begin{array}{l}\text { Clast to matrix-supported, boulder } \\
\text { to cobble. Local oversized clasts }\end{array}$ & $\begin{array}{l}\text { Carbonate, chert, mudstone } \\
\text { clasts and grains, detrital } \\
\text { clay }\end{array}$ & $\begin{array}{l}\text { Coarse-grained talus deposits } \\
\text { accumulated near cavity } \\
\text { walls and/or below vertical } \\
\text { pipes. Gravity-driven water } \\
\text { flows related to episodic } \\
\text { rainfall. Entrainment and } \\
\text { transport of carbonate and } \\
\text { mudstone clasts from top } \\
\text { bedrock and cavity fronts }\end{array}$ \\
\hline $\begin{array}{l}\text { Clast and } \\
\text { mud- } \\
\text { supported } \\
\text { gravel }\end{array}$ & $\begin{array}{l}\text { Crudely stratified to well- } \\
\text { stratified gravel deposits, metre- } \\
\text { thick clastic wedges. } \\
\text { Amalgamation of gravel beds } \\
\text { and alternation with mudstone }\end{array}$ & $\begin{array}{l}\text { Granules to pebbles, local cobbles. } \\
\text { Matrix-content ( }>40 \% \text { to }<5 \%) \text {. } \\
\text { Fining-upward clast-supported } \\
\text { beds }\end{array}$ & $\begin{array}{l}\text { Carbonate and mudstone, } \\
\text { minor chert. Matrix formed } \\
\text { of sand-grained carbonate } \\
\text { mixed with detrital clay }\end{array}$ & $\begin{array}{l}\text { High-viscosity flow evolving } \\
\text { down-slope into water-lain } \\
\text { deposits onto the uneven } \\
\text { floor of underground cavities. } \\
\text { Winnowing of fine particles } \\
\text { leading to thick mudstone } \\
\text { beds in ponded areas }\end{array}$ \\
\hline
\end{tabular}

Pebbly

sandstone

\begin{abstract}
Amalgamated medium to small-
\end{abstract} scale channel-fill bodies

evolving upwards into small

channel-fills, mudstone and

bar-like pebbly sandstone

bodies

Mudstone

Massive to vaguely laminated,

light greenish to greyish

mudstone as individualized,

up to $50 \mathrm{~cm}$ thick beds or

thinner beds associated with

gravel and sand
Sub-angular to sub-rounded pebbles to granules. Moderately sorted, occasionally silty-rich channel beds

Massive to vaguely laminate with variable amount of sand, silt and clay fractions
Carbonate and mudstone in pebble and sand fractions, minor clay composed of Al-smectite and illite, traces of kaolinite

Mainly detrital clay minerals (Al-smectite, detrital sepiolite and palygorskite
Episodic unidirectional flows entering pipes through gently dipping slopes balanced with deepening of the cavities. Association of pebbly sandstone and mudstone points to occlusion of the vertical pipes with eventual accumulation of massive mudstone

Episodic mudflow entering the cavities, settling-out of silt and clay particles from suspension in stream discharges of pebbly sandstone channels 
Table 1. (Continued)

\begin{tabular}{|c|c|c|c|c|}
\hline Lithofacies & Sedimentary features & Texture/fabric & Components & Interpretation \\
\hline Marlstone & $\begin{array}{l}\text { Massive to crudely bedded with } \\
\text { powdery appearance. Pale } \\
\text { greenish yellow to pinkish } \\
\text { grey. Slickenside surfaces } \\
\text { distributed in apparently } \\
\text { random pattern } \\
\text { Three sub-facies: (i) clastic-rich } \\
\text { marlstone (usual in lower } \\
\text { underground cavities); (ii) } \\
\text { massive calcareous marlstone; } \\
\text { and (iii) thinly bedded } \\
\text { calcareous marlstone (usual } \\
\text { in upper doline-like cavities). } \\
\text { Common lateral and vertical } \\
\text { changes among marlstone } \\
\text { sub-facies }\end{array}$ & $\begin{array}{l}\text { Clastic-rich marlstone composed } \\
\text { of poorly sorted, granule- to } \\
\text { sand grains. Clay content } \\
\text { variable. Graded bedding in } \\
\text { centimetre-thick beds. } \\
\text { Massive calcareous marlstone } \\
\text { formed of: (i) homogeneous } \\
\text { fossiliferous micrite; and (ii) } \\
\text { micrite displaying circum- } \\
\text { granular cracks and root-related } \\
\text { voids (palustrine fabric). } \\
\text { Thinly bedded calcareous } \\
\text { marlstone formed mainly of } \\
\text { fossiliferous micrite }\end{array}$ & $\begin{array}{l}\text { Carbonate and mudstone } \\
\text { granules and sand grains. } \\
\text { Carbonate content from } \\
40 \text { to } 75 \% \text { (average } 60 \% \text { ). } \\
\text { Minor quartz and feldspar. } \\
\text { Mainly detrital clay minerals } \\
\text { except for authigenic } \\
\text { sepiolite. Calcareous massive } \\
\text { and thinly bedded marlstone } \\
\text { composed of up to } 81 \% \text { low- } \\
\text { Mg calcite. Contrasted stable } \\
\text { carbonate isotope values from } \\
\text { marlstone deposits of lower } \\
\text { and upper parts of the } \\
\text { cavities }\end{array}$ & $\begin{array}{l}\text { Deposition of clastic-rich } \\
\text { marlstone mainly by episodic } \\
\text { mudflows in shallow water } \\
\text { ponding water located at the } \\
\text { lower subterranean cavities. } \\
\text { Composition of clastic-rich } \\
\text { marlstone points to extensive } \\
\text { reworking of bedrock. Local } \\
\text { water supply by ground- } \\
\text { water springs. } \\
\text { Accumulation of carbonate, } \\
\text { partly contributed by detrital } \\
\text { calcareous bedrock material, } \\
\text { in small shallow lakes } \\
\text { developed in surface doline- } \\
\text { like depressions. Evidence } \\
\text { for fluctuation in water level } \\
\text { of the lakes, resulting in } \\
\text { palustrine features within } \\
\text { the calcareous marlstone. } \\
\text { Stable isotope composition } \\
\text { of the upper marlstone } \\
\text { deposits indicative of evolved } \\
\text { waters in small closed-lake } \\
\text { basins. Differentiation of biota } \\
\text { assemblages occurring within } \\
\text { the various marlstone sub- } \\
\text { facies }\end{array}$ \\
\hline Nodular limestone & $\begin{array}{l}\text { Irregular, decimetric patches of } \\
\text { massive, indurate limestone } \\
\text { showing blocky to crudely } \\
\text { banded structure }\end{array}$ & $\begin{array}{l}\text { Network of fenestral-like voids } \\
\text { in dense, homogeneous micrite }\end{array}$ & $\begin{array}{l}\text { Limestone mostly composed } \\
\text { of low-Mg calcite (>90\%), } \\
\text { sand grains }\end{array}$ & $\begin{array}{l}\text { Accumulation of carbonate } \\
\text { related to groundwater } \\
\text { feeding springs locally present } \\
\text { at the subterranean cavities }\end{array}$ \\
\hline
\end{tabular}



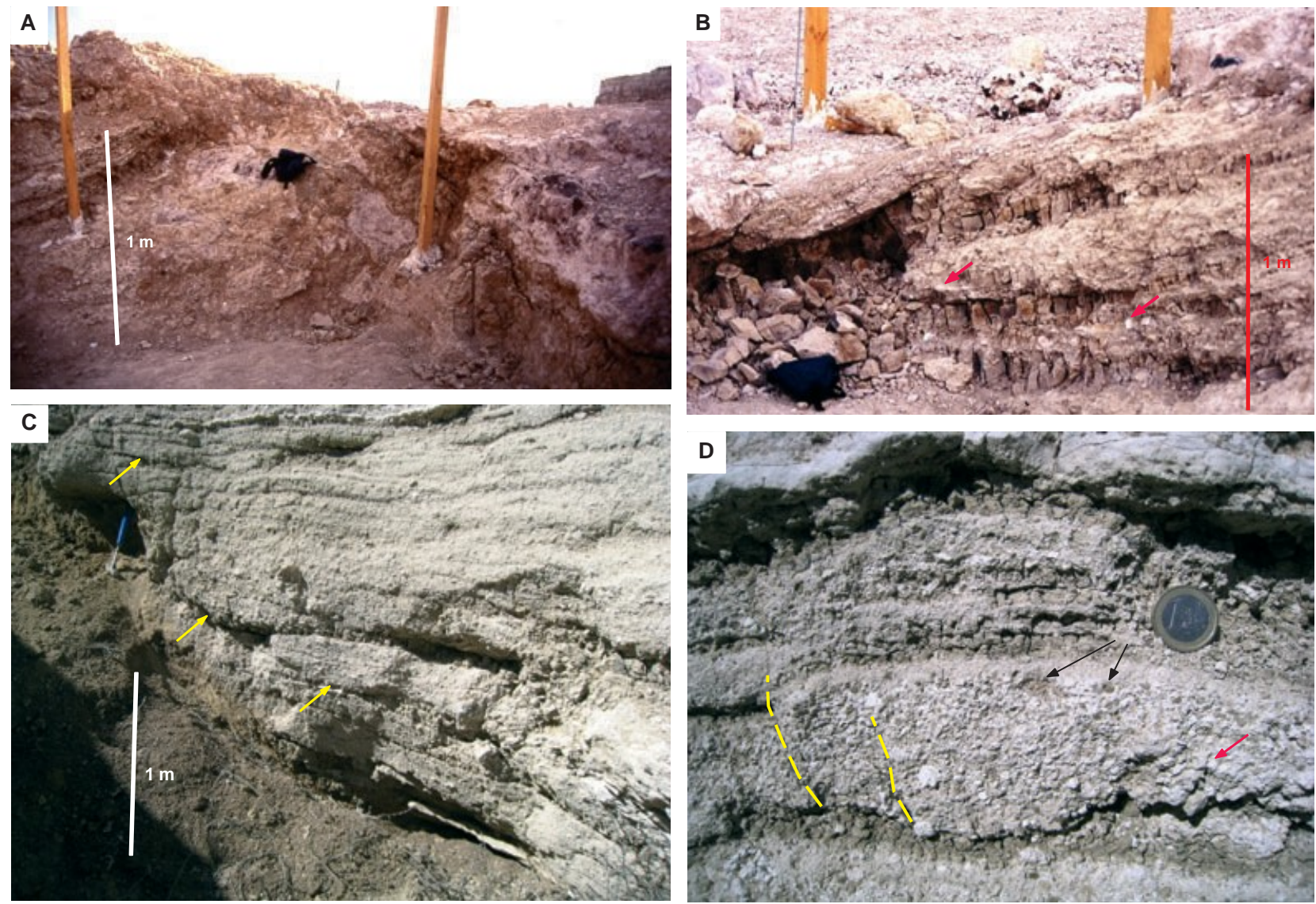

Fig. 10. (A) Outcrop showing gravel and breccia talus deposits at BAT-2. (B) Clast-supported gravel beds alternating with laminated mudstone; arrows point to carbonate clasts in the gravel beds; note that the thickness of the mudstone beds increases from right to left, thus defining flow direction. (C) Stacked pebbly sandstone beds in BAT-4; scouring (arrowed) is clearly observed at the central left side of the image. (D) Close-up view of a small channel filled by graded pebbly sandstone in BAT-9; small fissures at the left side of the channel result in step lowering allowing accommodation of an overlying pebbly sandstone channel; black arrows indicate mudstone clasts; red arrow indicates carbonate clast. Coin for scale is $23 \mathrm{~mm}$.

underground collapse induced by interstratal dissolution of underlying evaporite formations.

The deposits infilling the cavities repose unconformably both laterally and vertically on the surrounding bedrock, which indicates that the cavities were formed before the onset of sediment accumulation. The deposits are not distributed regularly because they locally show over-steepened bedding (dip up to $35^{\circ}$ ) near the cavity walls, small to medium-scale folds (Fig. 9A), and bedding is not continuous, but is usually disrupted by faults and slickenside planes (Figs 7C and 9B). Tilting of the infilling sedimentary packages is common. These deformational features point to differential compaction and possibly small to medium-scale subsidence of the cavity floor, in particular during the final phase of cavity sedimentary infill.

Both the vertical and lateral distribution of lithofacies was closely controlled by cavity extent, the passage irregularities and the proximity to the cavity walls. Six main lithofacies have been recognized. Major features shown by these lithofacies are summarized in Table 1.

\section{Gravel and breccia talus deposits}

\section{Description}

This lithofacies comprises steeply dipping (up to $30^{\circ}$ ), poorly stratified clast to matrix-supported gravel and breccia deposits of relatively limited extent and thickness (up to $1.5 \mathrm{~m}$ thick) showing a crude half-cone geometry (Fig. 10A). The deposits are usually located where vertical pipes enter the underground cavities. Clast sizes range from 8 to $25 \mathrm{~cm}$ (pebble to cobble). Oversized clasts up to $30 \mathrm{~cm}$ diameter are present locally. Carbonate clasts are found dominantly in the gravel and breccia deposits although chert boulders cover the cavity floor in some mammal 
Table 2. Summary of the main clay mineral assemblages identified in mudstone and marlstone deposits.

\begin{tabular}{lll}
\hline Clay mineral assemblage & $\begin{array}{l}\text { Name of mammal site and } \\
\text { horizon where the clay-bearing } \\
\text { deposit is located }\end{array}$ & Lithofacies type \\
\hline $\begin{array}{l}\text { Assemblage 1 } \\
\text { Al-smectite-illite-(kaolinite) }\end{array}$ & $\begin{array}{l}\text { Batallones-1-lower part } \\
\text { Batallones-3-lower part } \\
\text { Batallones-5-upper part } \\
\text { Batallones-6-lower part }\end{array}$ & $\begin{array}{l}\text { Gravel and breccia talus deposits } \\
\text { Clast and mud-supported gravel } \\
\text { Massive and laminated mudstone }\end{array}$ \\
$\begin{array}{l}\text { Assemblage 2 } \\
\text { Al-smectite-sepiolite-illite- }\end{array}$ & $\begin{array}{l}\text { Batallones-1-lower part } \\
\text { Batallones-2-lower part } \\
\text { Batallones-4-lower part }\end{array}$ & $\begin{array}{l}\text { Massive and laminated mudstone } \\
\text { Clastic-rich marlstone }\end{array}$ \\
$\begin{array}{l}\text { Assemblage 3 } 3 \\
\text { Al-smectite-illite-sepiolite- } \\
\text { kaolinite) }\end{array}$ & Batallones-9-upper part \\
Batallones-10-upper part & & Clastic-rich marlstone, \\
Assemblage 4 & Massive calcareous marlstone \\
Sepiolite-Al-smectite-illite & Thinly bedded marlstone \\
\hline
\end{tabular}

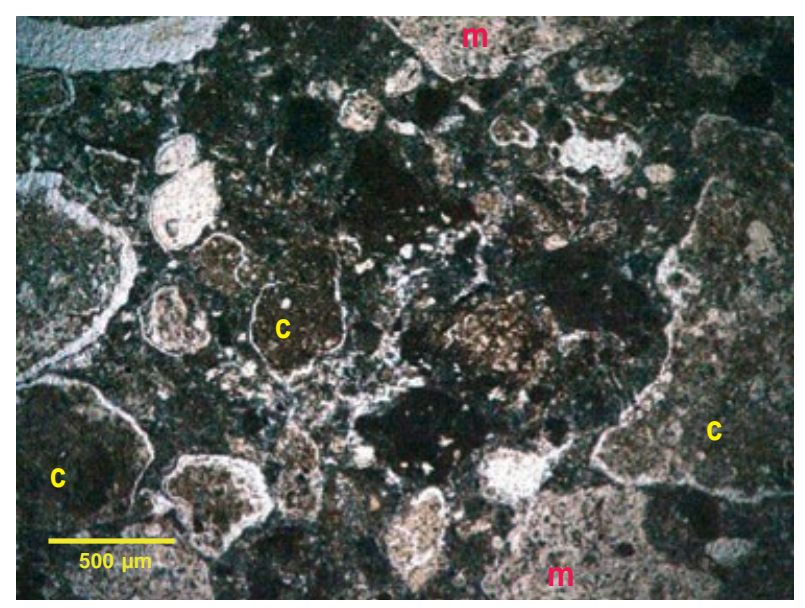

Fig. 11. Photomicrograph of pebbly sandstone filling the BAT-4 mammal site, P.P.L (plane polarized light). Note the angular shape of some grains, mainly formed of carbonate ' $\mathrm{c}$ ' and mudstone ' $\mathrm{m}$ '.

sites. Likewise, sub-angular to sub-rounded blocks and fragments of carbonate and mudstone pulled away from the cavity walls stand in lateral parts of conduits and vertical pipes. Clast size tends to fine both upwards and laterally within the basal gravel and breccia (Fig. 10A). Matrix consists mainly of sandy carbonate mixed with reddish (10R5/6) to brown (2.5YR4/ 6) detrital clays composed of Al-smectite, illite and minor kaolinite (clay mineral assemblage 1; Table 2). The deposits display local soft-sediment deformation, most commonly represented by over-steepened bedding.

\section{Interpretation}

The lithofacies represents subaerial talus accumulation of poorly sorted gravel and breccia adjacent to near-vertical cavity walls, mainly sourced through vertical pipes; their spatial distribution in the cavities was controlled mainly by gravity-driven water-flow episodically entering the hollows. Deposition was relatively rapid and the angle of repose of the sediment was occasionally exceeded, resulting in local softsediment deformation. These features resemble the gravel-rich colluvium deposits described by Laury (1980) from the late Quater- nary mammoth-bearing sinkhole site in South Dakota, USA, where the gravel talus deposits occur along most of the near-vertical sinkhole walls. In Cerro de los Batallones, the detrital components of the talus deposits were derived mostly from nearby source rocks, including mainly Units II and III of the bedrock. A signifi- cant part of the components was contributed by local rock-fall from both walls and ceilings. Chert rubble occurring on the floor of some cavi- ties is interpreted as a result of local collapse of underground chambers where the roof was formed of chert-rich sepiolite horizons.

\section{Clast and mud-supported gravel}

\section{Description}

The lithofacies comprises crudely to well-stratified gravel deposits where fabric ranges from mud-supported (matrix content higher than $40 \%$; Fig. 9A) to clast-supported gravel (occa- 
sionally the matrix content is less than $10 \%$ of the bed volume; Fig. 10B). These deposits are laterally related to gravel and breccia talus deposits. Clast sizes range from local cobbles to dominant pebble and granule. Clasts are subangular to sub-rounded and planar to subspherical in shape. Carbonate is the dominant component although mud clasts are abundant. The matrix is composed of carbonate sand with variable clay content comprising mainly detrital clays (clay mineral assemblage 1; Table 2) and fine-grained carbonate particles. The gravel beds occur as decimetre-thick, either amalgamated or alternating with mudstone. Stacked beds consist mainly of crudely stratified mud-supported gravel deposits arranged as clastic wedges that grade laterally into a facies association composed of alternating clast-supported, slightly graded gravel and reddish-brownish (10YR4/4) to greyish (10Y6/2) mudstone. In this facies association, the mudstone beds thicken downdip and their tops are gently scoured by the overlying clast-supported gravel beds (Fig. 10B). The lateral extent of the sedimentary wedges rarely exceeds $4 \mathrm{~m}$.

\section{Interpretation}

The matrix-supported clast deposits are interpreted to result from high-viscosity flows derived either from reworking of the gravel and breccia talus deposits or directly from debris flows moving onto the uneven floor of the underground cavities. Lateral facies change from matrix-supported to clast-supported gravel beds alternating with mudstone indicates segregation of the detritus-enriched flows from the entry point to more distant and relatively deeper parts of the cavities, a feature that is commonly observed in recent cave systems where sediment input occurs through localized entry points (for example, Victoria Fossil Cave, in South Australia; Reed, 2006). In Cerro de los Batallones, sediment was effectively distributed by episodic water flow of variable viscosity over the cavity floor, giving rise to small fan-like bodies where lobes are formed of mud-supported gravel. Cohesiveness of the debris-flows decreased progressively leading to branching systems of small channel bodies. Mudstone alternating with clast-supported gravel beds can be explained by winnowing of finer grains from the channel-fill bodies. This association of debris-flow and washed debris-flow deposits is common in alluvial fans (Blair \& McPherson, 1998; Blair, 1999), but it can also develop over much smaller scales in sediments infilling caves (Reed, 2006; Berger et al., 2008). Locally, the channels deviated where flows followed irregularities in the uneven floors of the cavity formed by roof-fall rubble.

\section{Pebbly sandstone}

\section{Description}

This lithofacies comprises mainly medium to small-scale channel-fill bodies (reaching $3 \mathrm{~m}$ in width and up to $40 \mathrm{~cm}$ thick) that occur either amalgamated or associated with light greenish (5GY6/1) mudstone beds. Sequences of stacked, pebbly sandstone channels showing gentle erosive bases (Fig. 10C) and reaching up to $4 \mathrm{~m}$ in thickness occur in BAT-4 and BAT-9. In these sites the pebbly sandstone sequences pinch out laterally towards the cavity walls (Fig. 9A) and, accordingly, they represent the sedimentary infilling of vertical pipes (Fig. 8). Upwards through the sections, the channel-fill bodies occur progressively separated by the greenish mudstone, which correlates with a decrease in the size of the channel-fill bodies and the more definite scoured channel bases (Fig. 10D), as well as local occurrence of small bar-like bodies made of the same components as in the channel-fills. Small bars are draped by mudstone. The clastic deposits are mainly composed of moderately sorted, graded carbonate and mudstone pebbles (Fig. 10D). Clast sizes in the channel-fill deposits range from $4 \mathrm{~cm}$ (pebbles) to less than $0.5 \mathrm{~cm}$ (granules). Clasts are dominantly carbonate, although mudstone is common (Figs 10D and 11).

\section{Interpretation}

Pebbly sandstone channels resulted from episodic stream flows entering the cavities. Amalgamation of the channel bodies implies that sediment supply by unidirectional flows was maintained while pipes were infilled. Lateral connection between pipes is not discounted, although there is no observational evidence for it. It is likely that gently sloping, not very long conduits (a maximum length of $10 \mathrm{~m}$ matches the dimensions of the observed outcrops at the surface of the butte) favoured input of reworked carbonate and mudstone material into the pipes during episodes of moderate rainfall. The vertical stacking of channel-fill bodies which retain both their geometry and thickness at the lower part of the sequences (Fig. 9A) strongly suggests that deposition of the clastic sediment kept pace with progressive subsidence of the cavity floor. Upward increase of interbedded pebbly 

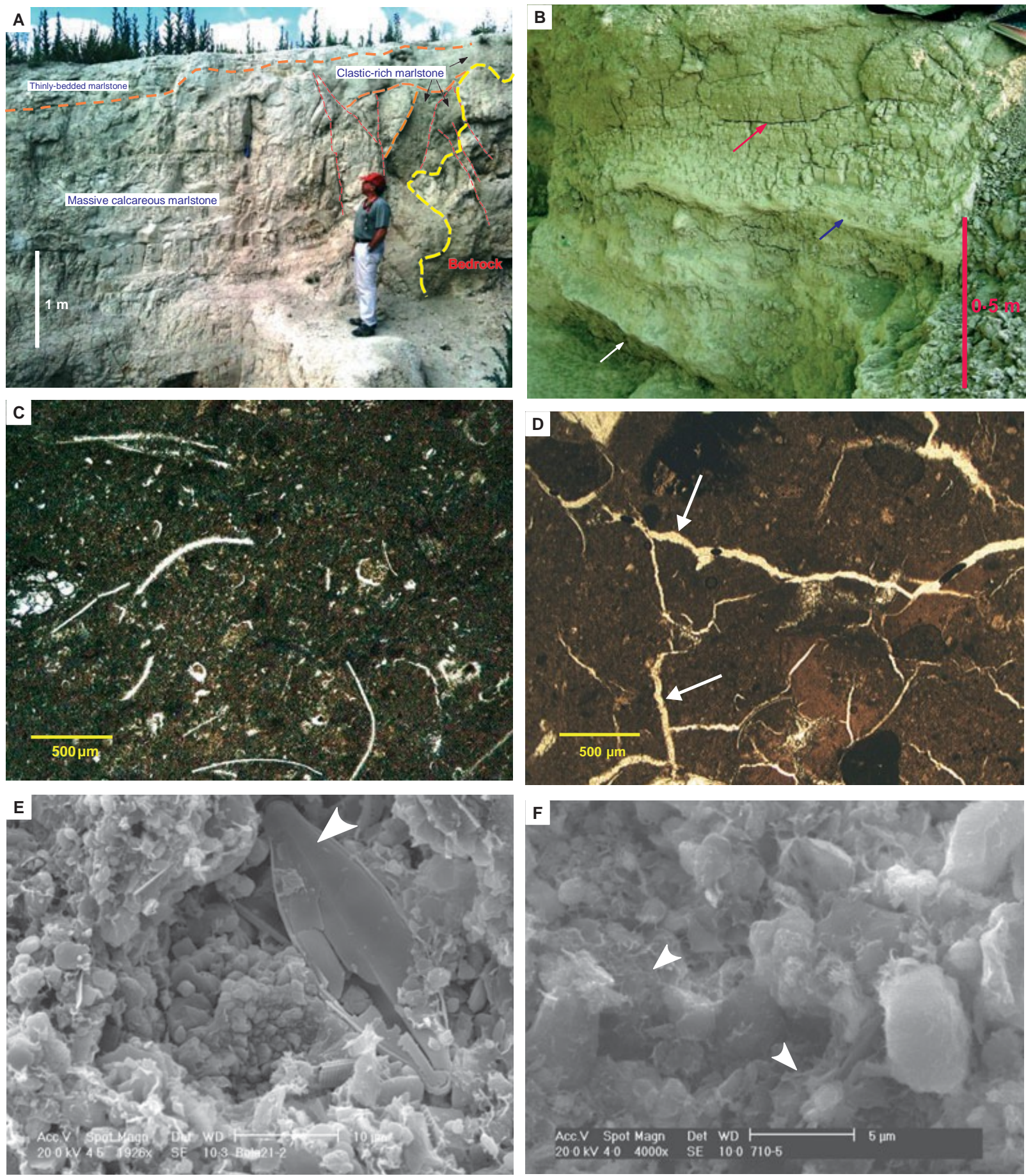

Fig. 12. (A) Outcrop showing marlstone lithofacies in BAT-5; two features can be clearly observed in the outcrop: bending of the marlstone beds and lateral facies change from clastic-rich marlstone deposits (at the right of the image) to massive calcareous marlstone; note the occurrence of thinly bedded marlstone capping the section; the dashed line indicates the location of the cavity wall. (B) Clastic-rich marlstone deposits comprising coarsegrained, graded beds showing sharp erosive contact (red arrow) over vaguely laminated, finer grained marlstone. These deposits accumulated in a subterranean cavity (BAT-1). The blue arrow points to the indurated carbonate crust; the white arrow at the base of the image points to a slickenside plane surface. (C) Photomicrograph of homogeneous fossiliferous micrite from thinly bedded calcareous marlstone (BAT-5). P.P.L. (D) Photomicrograph showing desiccation spar-filled microfractures (arrowed) developed in massive, ostracod-bearing micrite from BAT-5. P.P.L. (E) SEM image showing a pinnate diatom frustule (arrow) encased in an aggregate of minute (calcareous marlstone, BAT-5). (F) SEM image of massive calcareous marlstone showing micron-sized calcite crystals surrounded by fibre bundles of sepiolite (arrowed); uppermost part of BAT-7. 
Table 3. Carbonate stable isotope compositions from marlstone deposits.

\begin{tabular}{|c|c|c|}
\hline Sample & $d^{18} \mathrm{O}$ & $d^{13} C$ \\
\hline BAT 1-2 & $-6 \cdot 9$ & $-11 \cdot 3$ \\
\hline BAT 1-6 & $-6 \cdot 8$ & $-11 \cdot 4$ \\
\hline BAT 1-7 & $-6 \cdot 7$ & $-11 \cdot 2$ \\
\hline BAT 1-8 & $-6 \cdot 8$ & $-11 \cdot 1$ \\
\hline BAT $1-10$ & $-7 \cdot 0$ & $-11 \cdot 6$ \\
\hline BAT 1-06-07 & $-6 \cdot 3$ & $-11 \cdot 5$ \\
\hline BAT 1-5M & $-7 \cdot 0$ & $-12 \cdot 1$ \\
\hline BAT 1-5P & $-6 \cdot 1$ & $-11 \cdot 5$ \\
\hline BAT 1-A & $-7 \cdot 2$ & $-11 \cdot 4$ \\
\hline BAT 1-B & $-6 \cdot 6$ & $-11 \cdot 5$ \\
\hline BAT 1-C & $-7 \cdot 0$ & $-10 \cdot 7$ \\
\hline BAT 1-D & $-7 \cdot 1$ & $-11 \cdot 7$ \\
\hline BAT 2-1 & $-7 \cdot 2$ & $-10 \cdot 9$ \\
\hline BAT 2-2 & $-6 \cdot 9$ & $-10 \cdot 8$ \\
\hline BAT 2-5 & $-6 \cdot 8$ & $-10 \cdot 9$ \\
\hline BAT 2-6 & $-5 \cdot 3$ & $-8 \cdot 3$ \\
\hline ВАТ 2-9 & $-6 \cdot 9$ & $-11 \cdot 0$ \\
\hline BAT 2-11 & $-7 \cdot 5$ & $-10 \cdot 7$ \\
\hline BAT 2-08'-MON & $-6 \cdot 9$ & $-11 \cdot 1$ \\
\hline BAT 2-08ª-4 & $-6 \cdot 6$ & $-11 \cdot 3$ \\
\hline BAT $2-08^{a}-1 C$ & $-6 \cdot 4$ & $-10 \cdot 7$ \\
\hline BAT 4-5P & $-6 \cdot 0$ & $-10 \cdot 6$ \\
\hline BAT 4-11 & $-6 \cdot 9$ & $-11 \cdot 1$ \\
\hline BAT 4-14 & $-6 \cdot 1$ & $-10 \cdot 9$ \\
\hline BAT 4-15 & $-6 \cdot 6$ & $-11 \cdot 2$ \\
\hline BAT 4-16 & $-6 \cdot 5$ & $-11 \cdot 5$ \\
\hline BAT 4-17 & $-6 \cdot 0$ & $-10 \cdot 5$ \\
\hline BAT 4-19 & $-5 \cdot 9$ & $-10 \cdot 8$ \\
\hline BAT 5-17 & $-6 \cdot 1$ & $-9 \cdot 9$ \\
\hline BAT 5-18 & $-6 \cdot 2$ & $-9 \cdot 3$ \\
\hline BAT 5-19 & $-4 \cdot 1$ & $-7 \cdot 5$ \\
\hline BAT 5-20 & $-3 \cdot 7$ & $-6 \cdot 8$ \\
\hline BAT 5-21 & $-6 \cdot 1$ & $-9 \cdot 8$ \\
\hline BAT 5-22 & $-5 \cdot 7$ & $-9 \cdot 3$ \\
\hline BAT 5-23 & $-6 \cdot 4$ & $-10 \cdot 7$ \\
\hline BAT 5-FA & $-5 \cdot 9$ & $-9 \cdot 7$ \\
\hline BAT 5-FB & $-5 \cdot 0$ & $-8 \cdot 7$ \\
\hline BAT 5-FC & $-4 \cdot 3$ & $-7 \cdot 8$ \\
\hline BAT 5-FD & $-4 \cdot 9$ & $-8 \cdot 7$ \\
\hline BAT 7-03 & $-4 \cdot 7$ & $-9 \cdot 6$ \\
\hline BAT 7-04 & $-5 \cdot 2$ & $-10 \cdot 3$ \\
\hline BAT 7-05 & $-5 \cdot 2$ & $-9 \cdot 8$ \\
\hline BAT 7-06 & $-4 \cdot 4$ & $-9 \cdot 6$ \\
\hline BAT 7-07 & $-5 \cdot 5$ & $-9 \cdot 5$ \\
\hline BAT 7-08 & $-5 \cdot 2$ & $-9 \cdot 5$ \\
\hline BAT 7-09 & $-6 \cdot 1$ & $-9 \cdot 9$ \\
\hline BAT 7-10 & $-4 \cdot 4$ & $-7 \cdot 8$ \\
\hline BAT 7-11 & $-5 \cdot 5$ & $-8 \cdot 7$ \\
\hline BAT 7-12 & $-6 \cdot 0$ & $-9 \cdot 1$ \\
\hline BAT 9 RN1 & $-6 \cdot 6$ & $-11 \cdot 1$ \\
\hline BAT 9 RN3 & $-6 \cdot 4$ & $-10 \cdot 6$ \\
\hline BAT 9 RN7 & $-6 \cdot 7$ & $-10 \cdot 8$ \\
\hline BAT 9 RN9 & $-6 \cdot 3$ & $-10 \cdot 5$ \\
\hline BAT 9 RS4 & $-6 \cdot 5$ & $-11 \cdot 3$ \\
\hline BAT 9-17 & $-6 \cdot 0$ & $-9 \cdot 1$ \\
\hline BAT 9-18 & $-6 \cdot 0$ & $-9 \cdot 3$ \\
\hline
\end{tabular}

Table 3. (Continued)

\begin{tabular}{lrr} 
Sample & $d^{18} \mathrm{O}$ & \multicolumn{1}{c}{$d^{13} \mathrm{C}$} \\
\hline BAT 9-19 & $-5 \cdot 9$ & $-9 \cdot 4$ \\
BAT 9-20 & $-6 \cdot 3$ & $-10 \cdot 4$ \\
BAT 9-21 & $-6 \cdot 8$ & $-11 \cdot 2$ \\
BAT 9-26 & $-6 \cdot 9$ & $-10 \cdot 7$ \\
BAT 10 RN3 & $-6 \cdot 0$ & $-9 \cdot 1$ \\
BAT 10 RN4 & $-5 \cdot 9$ & $-9 \cdot 5$ \\
BAT 10 RN6 & $-6 \cdot 2$ & $-9 \cdot 8$ \\
BAT 10-FF & $-5 \cdot 5$ & $-8 \cdot 5$ \\
BAT 10-FM & $-5 \cdot 1$ & $-8 \cdot 3$ \\
BAT 10-FG & $-7 \cdot 0$ & $-10 \cdot 3$ \\
\hline
\end{tabular}

sandstone channels and mudstone indicates that the pipes became progressively plugged, the available accommodation space being filled by small channels and bars formed by aggradation and downstream migration of locally developed granular bedforms and by diluted mud. Similar depositional systems on a larger scale can be found in semi-arid regions where ephemeral fluvial streams (i.e. the 'rambla' system typical of some Mediterranean countries; Benito et al., 2010) result in significant reworking of former stream deposits.

\section{Mudstone}

\section{Description}

Mudstone occurs as various sub-facies within the sedimentary infill of the cavities. Clay and silt particles constitute part of, or the entire, matrix content in some of the coarse to medium-grained deposits described above. Where associated with clast and mud-supported gravel, the mudstone beds thicken away from the gravel forming decimetre-thick mudstone packages. Usually, these beds are vaguely laminated and locally contain a variety of freshwater fish remains. Moreover, light greenish (5GY6/1) to greyish (10Y6/2) laminated mudstone occurs associated with pebbly sandstone towards the upper part of the sequences filling vertical pipes, as is the case at BAT-4 and BAT-9 mammal sites. Up to $50 \mathrm{~cm}$ thick, light greenish (5GY6/1) massive mudstone deposits are usually observed in the transition from clastic to calcareous sediments. Locally, the mudstone deposits host well-preserved mammal skeletons, for example, a well-preserved, articulated giraffe skeleton occurs in BAT-4. The clay mineral composition of the latter mudstone deposits is characterized mainly by detrital clays where reworked 


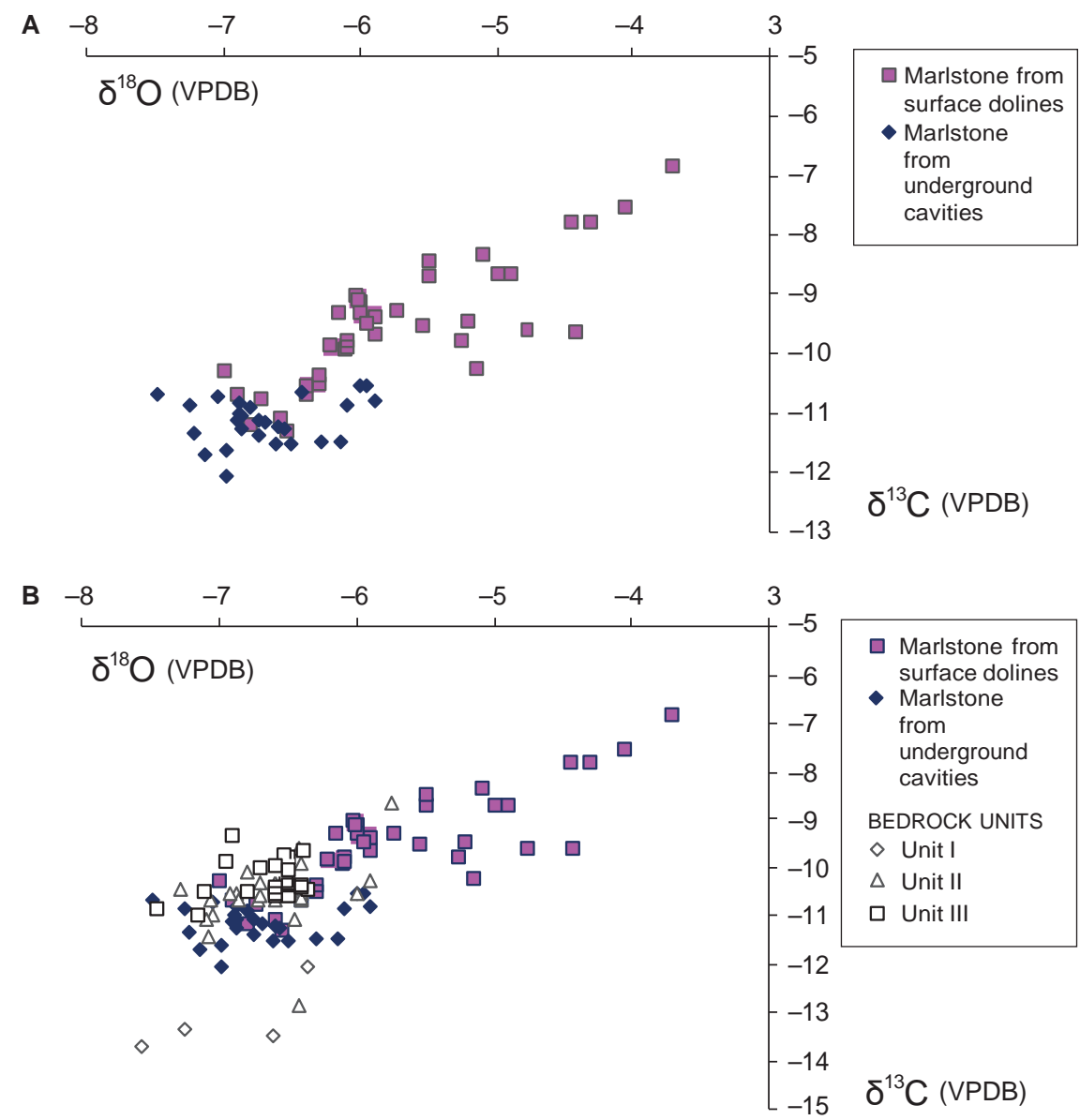

Fig. 13. (A) Cross-plot of stable isotope values from calcareous marlstone samples infilling both the upper and lower parts of the cavities in Cerro de los Batallones. (B) Cross-plot of $d^{18} \mathrm{O}$ and $\mathrm{d}^{13} \mathrm{C}$-values from calcareous marlstone infilling deposits and carbonates from bedrock units.

sepiolite and palygorskite have been preserved (clay mineral assemblage 2; Table 2).

\section{Interpretation}

Several origins can be proposed for the mudstone deposits in view of the various occurrences within the cavities. Most commonly, the mudstone was deposited after highly concentrated, turbulent mass-flows in which the mud was mixed with coarse gravel and sand fragments. A simple mechanism of settling-out of silt and clay particles after episodic discharge from streams entering the pipes can be postulated for the facies association composed of channel and bar-like pebbly sandstone bodies and laminated mudstone. Accumulation of massive mudstone filling and tapering vertical conduits can be explained by extensive massflow plugging the uppermost part of vertical pipes, thus contributing to effective sealing and flooring of the doline-like depressions located in the uppermost part of the cavities.
Marlstone

\section{Description}

The marlstone lithofacies comprises various lithological types composed of a mixture of terrigenous material, usually clay and silt particles and carbonate. The carbonate fraction in the marlstone can, in turn, be formed of calcareous detrital grains, fossil skeletons and chemical precipitates, chiefly calcite. Marlstone deposits infilling cavities in Cerro de los Batallones are relevant for two reasons: (i) the marlstone represents a significant part of the total volume of the sedimentary rocks of the cavities, occurring both in the lower subterranean chambers and in the upper doline-like cavities (Fig. 8); and (ii) the marlstone beds contain most of the fossil mammal remains found in Cerro de los Batallones.

Based on the component types and texture, three main marlstone sub-facies, i.e. clastic-rich marlstone, massive calcareous marlstone and thinly bedded calcareous marlstone, have been 
Table 4. Carbonate stable isotope compositions from bedrock units.

\begin{tabular}{|c|c|c|}
\hline Bedrock unit - Sample & $d^{18} \mathrm{O}$ & $d^{13} \mathrm{C}$ \\
\hline$\overline{I-1}$ & $-7 \cdot 6$ & $-13 \cdot 7$ \\
\hline $\mathrm{I}-2$ & $-7 \cdot 2$ & $-13 \cdot 4$ \\
\hline $\mathrm{I}-3$ & $-6 \cdot 6$ & $-13 \cdot 5$ \\
\hline $\mathrm{I}-4$ & $-6 \cdot 4$ & $-12 \cdot 1$ \\
\hline II-5 & $-6 \cdot 5$ & $-11 \cdot 1$ \\
\hline II-6 & $-7 \cdot 3$ & $-10 \cdot 5$ \\
\hline II-7 & $-6 \cdot 9$ & $-10 \cdot 6$ \\
\hline II-8 & $-7 \cdot 1$ & $-10 \cdot 7$ \\
\hline II-9 & $-6 \cdot 7$ & $-10 \cdot 7$ \\
\hline II-10 & $-6 \cdot 8$ & $-10 \cdot 7$ \\
\hline II-11 & $-7 \cdot 0$ & $-11 \cdot 0$ \\
\hline II-12 & $-6 \cdot 4$ & $-9 \cdot 6$ \\
\hline II-13 & $-7 \cdot 1$ & $-11 \cdot 4$ \\
\hline II-14 & $-5 \cdot 8$ & $-8 \cdot 6$ \\
\hline II-15 & $-6 \cdot 9$ & $-10 \cdot 5$ \\
\hline II-16 & $-7 \cdot 1$ & $-11 \cdot 1$ \\
\hline II-17 & $-6 \cdot 4$ & $-12 \cdot 8$ \\
\hline II-18 & $-6 \cdot 4$ & $-10 \cdot 7$ \\
\hline II-19 & $-6 \cdot 8$ & $-10 \cdot 1$ \\
\hline II-20 & $-6 \cdot 4$ & $-10 \cdot 5$ \\
\hline II-21 & $-6 \cdot 4$ & $-10 \cdot 6$ \\
\hline II-22 & $-6 \cdot 7$ & $-10 \cdot 6$ \\
\hline II-23 & $-5 \cdot 9$ & $-10 \cdot 3$ \\
\hline II-24 & $-6 \cdot 6$ & $-10 \cdot 7$ \\
\hline II-25 & $-6 \cdot 5$ & $-10 \cdot 6$ \\
\hline II-26 & $-6 \cdot 4$ & $-10 \cdot 6$ \\
\hline II-27 & $-6 \cdot 7$ & $-10 \cdot 3$ \\
\hline II-28 & $-6 \cdot 4$ & $-9 \cdot 9$ \\
\hline II-29 & $-6 \cdot 6$ & $-10 \cdot 3$ \\
\hline II-30 & $-6 \cdot 0$ & $-10 \cdot 6$ \\
\hline III-31 & $-6 \cdot 6$ & $-10 \cdot 5$ \\
\hline III-32 & $-6 \cdot 5$ & -9.8 \\
\hline III-33 & $-6 \cdot 4$ & $-9 \cdot 6$ \\
\hline III-34 & $-6 \cdot 4$ & $-10 \cdot 5$ \\
\hline III-35 & $-6 \cdot 9$ & $-9 \cdot 4$ \\
\hline III-36 & $-6 \cdot 9$ & $-9 \cdot 9$ \\
\hline III-37 & $-7 \cdot 1$ & $-10 \cdot 5$ \\
\hline III-38 & $-7 \cdot 5$ & $-10 \cdot 9$ \\
\hline III-39 & $-6 \cdot 5$ & $-9 \cdot 7$ \\
\hline III-40 & $-6 \cdot 5$ & $-10 \cdot 3$ \\
\hline III-41 & $-7 \cdot 2$ & $-11 \cdot 0$ \\
\hline III-42 & $-6 \cdot 5$ & $-10 \cdot 1$ \\
\hline III-43 & $-6 \cdot 5$ & $-10 \cdot 4$ \\
\hline III-44 & $-6 \cdot 6$ & $-10 \cdot 0$ \\
\hline III-45 & $-6 \cdot 4$ & $-10 \cdot 4$ \\
\hline III-46 & $-6 \cdot 5$ & $-10 \cdot 6$ \\
\hline III-47 & $-6 \cdot 6$ & $-10 \cdot 5$ \\
\hline III-48 & $-6 \cdot 4$ & $-10 \cdot 4$ \\
\hline III-49 & $-6 \cdot 8$ & $-10 \cdot 5$ \\
\hline III-50 & $-6 \cdot 6$ & $-10 \cdot 6$ \\
\hline III-51 & $-6 \cdot 6$ & $-10 \cdot 4$ \\
\hline III-52 & $-6 \cdot 7$ & $-10 \cdot 0$ \\
\hline III-53 & $-6 \cdot 6$ & $-10 \cdot 5$ \\
\hline
\end{tabular}

distinguished (Table 1 and Fig. 12A). Besides differences in texture and fabric, the marlstone sub-facies show mineralogical and geochemical variations that are related to their stratigraphic distribution within the sites.

The clastic-rich marlstone, pale greenish yellow (10YR8/2) in colour, is composed of intermediate to poorly sorted, granule to sand-sized carbonate grains that usually contain a finegrained matrix made of clay and/or calcareous silt. The carbonate grains consist mainly of micrite and/or microsparite. The marlstone occurs as centimetre to decimetre-thick beds. Coarser grained clastic-rich marlstone deposits show erosive bases and fining-upward grading (Fig. 12B), whereas finer grained beds are massive or vaguely laminated. The clastic-rich marlstone deposits occur mainly in the lower part of the cavities where they are laterally related to alternating clast-supported gravel and mudstone beds. However, clastic-rich marlstone is also present in the surface doline-like parts of the sites. Therein, this lithofacies occurs at the marginal parts of the depressions, where the clasticrich marlstone unconformably overlies the detrital and carbonate deposits of Unit III (Figs 9A and 12A). In these locations, the marginal clasticrich marlstone deposits show rapid gradational lateral and upward interfingering with calcareous marlstone towards the centre of the depressions.

Massive and thinly bedded calcareous deposits are pale greenish yellow (10YR8/2) to pinkish grey (5YR8/1) in colour and are composed mainly of carbonate micrite with variable amounts of terrigenous silt and clay $(<0.08 \mathrm{~mm})$ and occasional up to $1.5 \mathrm{~mm}$ carbonate clasts, floating in the groundmass. Carbonate in the marlstone is formed exclusively of low-Mg calcite. The marlstone exhibits two main microfacies: (i) fossiliferous micrite (Fig. 12C), where bioclasts comprise mainly broken and complete ostracod and gastropod shells, gyrogonites, plant debris and occasional vertebrate remains; and (ii) micrite showing circum-granular cracks and rootrelated voids with scarce skeletons (Fig. 12D). Analysis of the ultrastructure under the SEM shows that the marlstone is composed of minute (2 to $3 \mathrm{Im}$ ) sub-rhombohedal calcite crystals mixed with clays and broken and complete pinnate diatom frustules (Fig. 12E), occasionally with other siliceous components such as phytolites and sponge spicules. This view is different from some marlstone deposits, for instance in BAT-7, where the marlstone fabric shows recrystallised calcite (5 to $7 \mathrm{Im}$ ) interspersed with authigenic clay minerals comprising fibre bundles of sepiolite that coat the calcite crystals (Fig. 12F). Clay mineral assemblages determined 

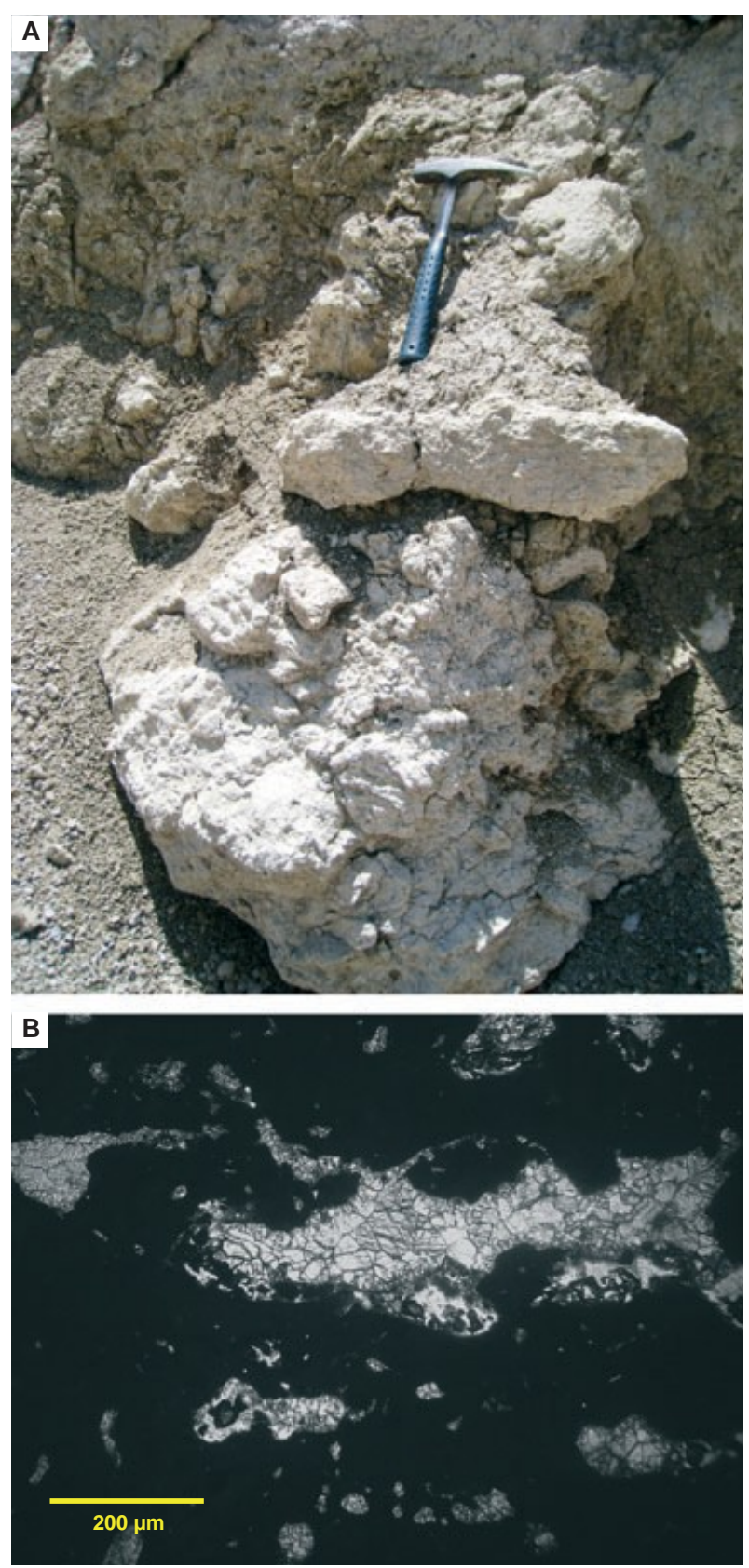

Fig. 14. (A) Outcrop view of a nodular limestone patch from BAT-2 (hammer for scale is $33 \mathrm{~cm}$ long). (B) Photomicrograph of nodular limestone showing extensive development of fenestral texture in dense carbonate micrite. P.P.L.

in the marlstone lithofacies are shown in Table 2.

The occurrence of massive and thinly bedded marlstone bearing fossil invertebrate remains and diatoms is registered mainly in the upper doline-like deposits of the cavities. However, massive and thinly bedded calcareous marlstone deposits occur locally associated with clasticrich marlstone in the subterranean cavities
(Fig. 12B). In this case, marlstone comprises fossiliferous micrite with abundant ostracod shells, scarce fragments of gastropods and reworked plant remains. No fossil remains of organisms which need light to grow, for example, charophytes and diatoms, are found in these marlstone deposits.

\section{Isotope geochemistry of marlstone}

Stable isotope carbonate values vary between $-3 \cdot 7 \%$ and $-7 \cdot 5 \%$ for $d^{18} \mathrm{O}$, and between $-6 \cdot 8 \%$ and $-12 \cdot 1 \%$ for $\mathrm{d}^{13} \mathrm{C}$ within all the analysed calcareous marlstone samples (Table 3 ). However, oxygen and carbon isotope compositions from the marlstone deposits which accumulated in lower and upper parts of the cavities are arranged in different fields when represented in a cross-plotted $\mathrm{d}^{18} \mathrm{O}-\mathrm{d}^{13} \mathrm{C}$ diagram (Fig. 13A). As shown in the figure, samples collected from marlstone accumulated in the subterranean cavities show weak correlation values, whilst marlstone samples from deposits which accumulated in the upper doline-like depressions show isotopic covariance (Fig. 13A). The clustering of isotopic compositional values that occur clearly differentiated in the plots suggests varied origins and/or processes for the formation of the marlstone facies (see discussion below). A second step for the evaluation of isotopic data led to the comparison of the isotopic compositions of carbonate from the calcareous marlstone infilling the cavities (Table 3 ) and those obtained from the bedrock (Table 4). As shown in Fig. 13B, $d^{18} \mathrm{O}$ and $\mathrm{d}^{13} \mathrm{C}$-values from bedrock carbonate plot close, partially overlapping $\mathrm{d}^{18} \mathrm{O}$ and $\mathrm{d}^{13} \mathrm{C}$-values from marlstone deposits of the subterranean cavities.

\section{Interpretation}

Based on the different sub-facies and their distribution in the cavities, two different scenarios for the formation of marlstone deposits can be drawn: (i) accumulation of fine-grained carbonate (from granule to silt size) in water ponding the floor of underground cavities; and (ii) biochemical precipitation of carbonate micrite and accumulation of calcareous and siliceous skeletons in small lake basins, i.e. surface doline-like depressions. In the former case, the marlstone could be classified properly as calclithite (sensu Tucker, 2001), where a significant contribution of clastic carbonate detritus was mainly related to erosion of calcareous deposits of Unit III, although calcite rhizocretions and nodules in sepiolite deposits of Unit II worked as an additional carbonate source. Besides petrographic 


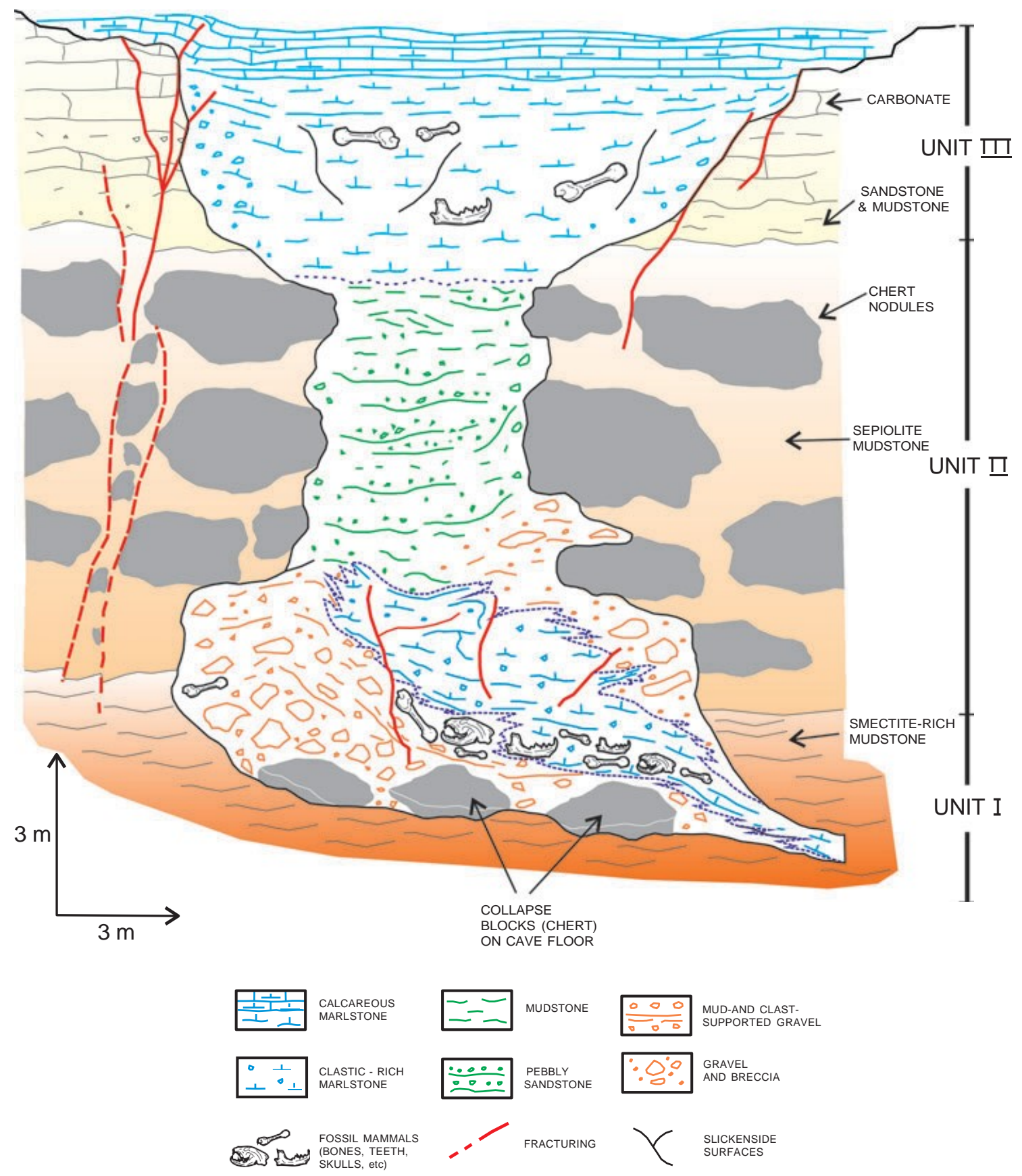

Fig. 15. General model of sedimentary infilling of the cavities containing fossil mammals in Cerro de los Batallones (see explanation in text). Note that major concentrations of mammal bones (locally forming a 'bone-breccia') occur in the basal parts of the subterranean cavities.

similarity of the carbonate grains, this is supported by the facies relations among clastic deposits that, as a whole, display a grain-fining trend across the sediment floor of the subterranean chambers. In this setting, alternation of coarse and fine-grained marlstone indicates changes in the energy of flows supplying carbonate detritus to the ponds developed over the cavity floor. Thick, slightly graded clastic- rich marlstone beds showing slightly erosive bases can be interpreted as a result of relatively concentrated mass-flows, whilst vaguely laminated, finer grained clastic-rich marlstone probably derived from more dilute mudflows. Local occurrence of carbonate crusts intercalated in the marlstone (Fig. 12B) points to probable early diagenetic lithification of the fine-grained deposit in the underground ponds. 


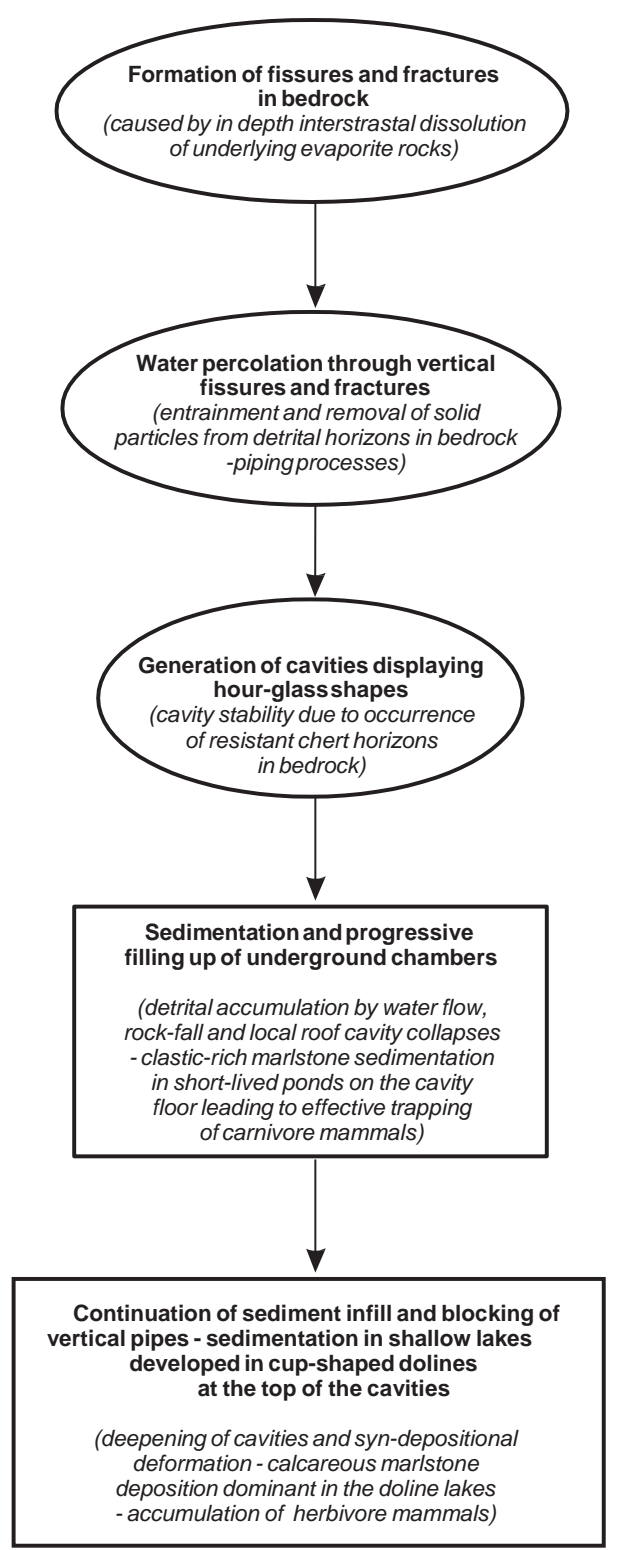

Fig. 16. Summary diagram showing the successive stages of generation of cavities and subsequent sedimentary infilling episodes leading to the formation of Cerro de los Batallones mammal sites.

The similarity of isotopic carbonate compositions from the source bedrock and the marlstone deposits of the subterranean cavities (Fig. 13B) can be used as additional evidence to support a detrital origin for the carbonate in the marlstone through erosion of the nearby bedrock. Slightly lighter $d^{13} \mathrm{C}$-values in the marlstone samples could indicate some contribution of organicderived ${ }^{13} \mathrm{C}$-depleted carbon through water fed by underground springs, but this has not yet been studied in detail. In contrast, most of the $d^{18} \mathrm{O}$ and $\mathrm{d}^{13} \mathrm{C}$-values obtained from the upper doline marlstone deposits (Fig. 13A) can be explained by carbonate precipitation from shallow lake waters that underwent evaporative enrichment (Bellanca et al., 1992; Deocampo, 2010). For the interpretation of these isotopic values, an evaluation of the diagenetic overprint was carried out by observation of SEM images of the marlstone. Both the minute size and the subrhombohedral shape of most of the calcite crystals (Fig. 12E) seem to indicate that they have not undergone significant diagenetic transformation and accordingly they show an original isotopic signature. This is not the case, however, for the recrystallised calcite observed in some of the marlstones. In general, the isotopically depleted carbonate suggests that the ponds contained dilute, freshwater. The consistently negative $\mathrm{d}^{18} \mathrm{O}$ signature of the low-magnesian calcite in all marlstone samples points to precipitation from an ${ }^{18} \mathrm{O}$-poor meteoric source. Covariance of oxygen and carbon data is consistent with closed basin lake conditions (Talbot, 1990; Calvo et al., 1995a; Paz \& Rossetti, 2006). The $d^{13} \mathrm{C}$ values from surface doline marlstones are low, suggesting contribution of soil-derived $\mathrm{CO}_{2}$ that probably records the occurrence of vegetated areas around the shallow lake basins (Bellanca et al., 1992; Benson et al., 1996).

The occurrence of clastic-rich marlstone deposits in the margins of the surface dolinelike depressions indicates erosion and reworking of limestone from Unit III. However, most of the carbonate in the shallow lakes is autochthonous, as evidenced by fabric and components. Palustrine features in the calcareous marlstone are indicative of very shallow to intermittently exposed depositional conditions (Platt \& Wright, 1992; Alonso-Zarza, 2003; Alonso-Zarza \& Wright, 2010). Calcareous invertebrate skeletons from the fossiliferous micrite fabrics are also typical of shallow lake basins. Moreover, the abundance of pinnate diatom frustules in the surface marlstone shows similarities with the upper Miocene small lake basins occurring in nearby areas of the Madrid Basin (Bellanca et al., 1992). The lake-level was low but stable, and the water clean and fresh enough to allow growth of charophytes and development of benthic diatoms. The surface area of the lakes was constrained by the size of the doline-like depressions; a maximum extent of about $150 \mathrm{~m}^{2}$ is estimated (for example, the BAT-10 mammal site). 
Nodular limestone

Description

Patches of massive to banded, indurated limestone characterized by an extensive network of voids and brecciated fabric occur locally associated with deposits occupying underground cavities. The patches exceed $0.5 \mathrm{~m}$ in height and show irregular geometries (Fig. 14A). The fabric of the nodular limestone comprises dense micrite displaying well-developed fenestral vugs filled by spar crystals (Fig. 14B) and scarce detrital quartz grains. The limestone is composed exclusively of low-Mg calcite.

\section{Interpretation}

The nodular limestone is interpreted to result from carbonate deposition by groundwater spring feeders located close to the subterranean cavities. Similar carbonate deposits related to springs are found locally in areas adjacent to Cerro de los Batallones (Bellanca et al., 1992; Calvo et al., 1995b). In the Madrid Basin, they are representative of groundwater recharge into more or less developed lake systems throughout the Miocene. Laury (1980) described the role played by spring feeders as a major mechanism of water supply into a sinkhole lake working as a trap for a concentration of mammoth remains in South Dakota. A comprehensive description and interpretation of spring systems and their deposits in continental settings can be found in Jones \& Renaut (2010).

\section{Lithofacies relations and sedimentary infill pattern}

Variations in thickness and frequent lateral facies changes are typical of cave sediments because of the irregular geometry of the cavities and pipes and walls that control internal sediment transport and depositional processes (White, 2007; Berger et al., 2008). The sedimentary infill pattern of the cavities at Cerro de los Batallones is characterized by a change from dominantly clastic sedimentation in the lower subterranean chambers and within the intervening chimneys to predominantly biochemical carbonate deposition in the cup-shaped dolines forming the upper part of the cavities. This trend in the distribution of the different lithofacies allows a model to be proposed for the cavity fill (Fig. 15) even though the sedimentary deposits have not been totally excavated at some sites. A summary of the evolution of the cavities in Cerro de los Batallones and their subsequent sedimentary infill is presented in Fig. 16.

\section{Generation of cavities}

The bedrock at Cerro de los Batallones is mostly formed of non-soluble rocks. Except for the carbonate and sandstone deposits of Unit III (Fig. 5), the bedrock is mainly mudstone possessing a varied clay mineralogy (Galan \& Pozo, 2011). Nevertheless, the cavity system resembles that formed in typical karst settings, a geological situation that has been referred to as 'pseudokarst' (Floridia, 1941). In an overview on the topic, Halliday (2007) provided a simple definition of pseudokarst as: "karst-like morphology primarily produced by a process other than dissolution" and identified eight types of pseudokarst. One of the types is caves resulting from piping, i.e. natural development of subsurface drainage in detrital rocks where solid particles are removed and transported in suspension by water flow (Parker, 1963; Bryan \& Yair, 1982; Bryan \& Jones, 1997). Piping is envisaged as a geomorphological process for the generation of cavities in Cerro de los Batallones. Alternative processes, such as simple top-down erosion by gullying or formation of blind or pocket valleys located close to, or at the edges of the butte, are not consistent with the occurrence of individual cavities at the central part of the butte (Fig. 8).

Formation of piping caves in Cerro de los Batallones began at inflow sites provided by fissures and faults resulting from in-depth interstratal dissolution of underlying gypsum and sodium sulphate-bearing formations (Rodríguez-Aranda et al., 2002). Multiple vertical and oblique planar discontinuities within the mudstone bedrock units represent effective flow paths for the development of piping within the sedimentary sequence. Moreover, subsurface shrinkage ruptures could extend a few metres upwards to the ancient ground surface, thus creating elongated depressions that eventually evolved into sinkholes (Figs 4 and 7).

The depth of the surveyed cavities provides evidence for a steep hydraulic gradient between the ground surface and the groundwater table capable of producing subsurface erosion by piping. As indicated by the Electric Resistivity Tomography (ERT) surveys, the maximum measured depth of the pipe cavities is about $15 \mathrm{~m}$ and the pipes did not reach bedrock deposits located below Unit I. Smectite-rich clays of this 
basal unit are very cohesive and compact enough to behave as an impermeable horizon. However, probable cavity outlets are not observable in the investigated outcrops so there is no clear evidence regarding how and where the ancient piping system discharged. One possibility is downward leakage of the sediment removed from bedrock throughout the pathways generated by vertical fissures and tracks formed after dissolution of underlying evaporites. An alternative possibility is the existence of active narrow lateral passages at the top of the non-permeable mudstone deposits of Unit I, which would result in discharge at points along the ancient relief. The recognition of several generations of palaeo-flatirons and other fossilized geomorphological features, especially along the western side of the butte (Fig. 4), may support this interpretation.

\section{Cavity stability}

Over the long-term, mudstone or piping cavities are not stable landforms, but show annual changes in both their formation and evolution, especially in badland settings (Bryan \& Jones, 1997). The fine grain size and weak cohesiveness of the deposits in which piping is usually developed account for frequent ceiling and/or wall collapses of tunnels and conduits (Zhu et al., 2002). Because of this, the preservation potential of piping cavities in the geological record is low. However, in Cerro de los Batallones, the occurrence of indurated resistant chert horizons interstratified in the bedrock was a key factor favouring the development, differential enlargement and prolongation of the survival time of open cavities. Chert is particularly abundant in Unit II (Fig. 6) where it commonly occurs as isolated nodules up to a metre in diameter and as laterally limited chert horizons up to $4 \mathrm{~m}$ thick within sepiolite mudstone. According to Bustillo \& Alonso-Zarza (2007), the chert horizons can be interpreted as phreatic silcretes (sensu Thiry, 1997).

Discontinuities in the chert horizons generated preferential pathways, which concentrated subsurface inflow and focused erosive activity at certain points, which developed into caves - piping enlargement beneath the resistant impermeable horizons. This could eventually give rise to the sagging and partial collapse of the sedimentary sequence overlying the chert horizons. As a result, relatively large caves formed underneath the vertical pipes.
RELATION BETWEEN SEDIMENTARY

INFILL PATTERN AND FOSSIL

MAMMAL ASSEMBLAGES

The fossil mammal sites of Cerro de los Batallones have yielded abundant palaeontological information that was published by Morales et al. (2008), and references therein. Papers by Anton et al. (2004), Peigne et al. (2008), Salesa et al. (2009), Sanchez et al. (2009), Lopez-Antoñanzas et al. (2010) and Domingo et al. (2011), among others, deal with specific vertebrate taxa, palaeoecological inference from the numerous mammal groups present, and taphonomic features of the fossil concentrations. One long-held assumption (Morales et al., 1992, 2004) is that the mammal sites of Cerro de los Batallones formed in cavities that functioned as traps for a variety of animals. This conclusion is based on the overwhelming occurrence of carnivore remains, which comprise more than $95 \%$ of the collected bones in some mammal sites (BAT-1 and BAT-3).

Major concentration of carnivore remains, even resulting in formation of 'bone-breccia', is found in marlstone deposits which accumulated on the floor of the subterranean chambers. Therein, the bones littered the uneven floor of the cavity that was usually covered by chert boulders. In contrast, herbivore-dominated mammal assemblages are commonly found in the calcareous marlstone deposits, which accumulated in the surface doline-like depressions at the upper part of the cavity-pipes (Fig. 15). Sediments accumulated in vertical conduits of pipes are usually barren or contain sparse isolated bones.

The accumulation of carnivore fossils in the cavity marlstones indicates selective trapping of carnivore taxa. Bones of sabre-toothed cats, amphycyonids, ailurids, bears and other carnivores deposited in the marlstone show excellent preservation and mostly occur as semi-articulated skeletons. Taphonomic studies based on Rare Earth Element (REE) analysis of bones from Cerro de los Batallones mammal sites (Domingo et al., 2011) suggests that an oxic environment existed where they were concentrated. In this setting, marlstone represents deposition from relatively permanent water bodies, which is supported by the presence of fish and amphibians as well as some aquatic invertebrate remains in the marlstone groundmass. Access to water is considered to have been a major reason for animals to enter the cavities, a foraging practice characterized as one of the main biotic autochthonous processes that incorporate vertebrates 
into caves (Simms, 1994). Lack of surface water during periods of prolonged drought can explain the attraction of cave pools for a large number of animals including many that were inexperienced in evaluating the risk of being trapped. Recent and fossil tunnels and other conduits can result from the subterranean activity of mammals and building of palaeocaves could be considered as a particular case of burrowing (Busch et al., 2000; Genise \& Farina, 2012). This mechanism cannot be applied to the formation of the cavities of Cerro de los Batallones. Both the size and the shape of the cavities exclude such an interpretation.

The interpretation of the predominance of herbivore mammal remains in marlstone from the upper part of the cavity shafts (Fig. 15) differs markedly from that explaining the accumulation of carnivores. The scenario envisaged for the accumulation of large herbivore mammals, such as mastodons, giraffes, rhinos and horses, is similar to that described as water-hole trap accumulations by Simms (1994). In this setting, the surface water bodies were visited by animals unaware of the existence of steep-sided depressions and even though the water depth is insufficient to cause drowning of large vertebrates, the steepness or slipperiness of the sides may prevent their escape and bring about death by starvation.

\section{CONCLUDING REMARKS}

The mammal-bearing cavities of Cerro de los Batallones formed as a result of piping. The unusually prolonged survival time of the cavities as open subterranean spaces was strongly conditioned by the occurrence of chert horizons in the Miocene bedrock hosting the cavities, which enhanced the stability of vertical conduits and rocky oversteps. The combination of piping and differential subterranean erosion sustained by randomly distributed rocky chert bodies allowed the cavities to work as effective and selective mammal traps and led to unexpected preservation of a pseudokarst context.

The sedimentary infillings conformed to the hourglass geometry of the non-interconnected cavities. This geometry resulted from belllike underground cavities linked to the surface cup-shaped depressions via vertical pipes or chimneys.

The sedimentary infill of the fossil mammalbearing cavities in Cerro de los Batallones is mainly composed of clastic and calcareous marl- stone deposits, the former being abundant in the lower subterranean cavities and vertical pipes, whilst the latter are the dominant lithofacies in the upper parts of the depressions. The marlstone deposits, which contain most of the fossil remains at the mammal sites, are present both in the lower subterranean chambers and in the upper dolines located at the top of the vertical cavity pipes. Stable isotope compositions of marlstone deposited in the upper dolines can be clearly discriminated from those determined in marlstone deposits from the lower subterranean cavities, thus pointing to different palaeoenvironmental conditions for marlstone deposition and the different origin of the carbonate. This agrees with the differences in faunal assemblages recorded in the lower and the upper part of the fossil sites. Fossil mammal sites of Cerro de los Batallones provide a good example of the statement by Simms (1994) that significance of trap sites is disproportionate to the relatively small volume of sediment which they contain.

\section{ACKNOWLEDGMENTS}

The authors thank Marian Álvarez-Sierra (Universidad Complutense, Madrid) Arantza Aranburu (Universidad del Pais Vasco), Alfredo P’erez González (CENIEH), David Gomez-Gras (Universidad Autonoma de Barcelona), Ramón Mas (Universidad Complutense, Madrid), Luis Alcala (Fundación Conjunto Paleontologico de Teruel-Dinopolis), Alfredo Arche (Instituto de Geociencias, CSIC), Cecilio Quesada (Spanish Geological Survey, IGME) and Thomas Stevens (Royal Holloway, University of London) for their valuable scientific comments. Martin Pickford (Museum National d'Histoire Naturelle de Paris) helped to improve the English language. Geophysical research surveys, were undertaken by T'ecnicas Geofisicas S.L. (Avila, Spain); collaborations of Pedro Carrasco-Morillo and Pedro Carrasco-Garcia are acknowledged. Soledad Domingo and members of the Palaeontology team working on the mammal sites of Cerro de los Batallones are thanked for their consistent scientific assistance. Thanks to Chief Editor of Sedimentology Peter K. Swart and Associate Editor David Mallinson for their excellent, thorough editorial work. We are indebted to three anonymous reviewers who greatly contributed to improving the organization and contents of the manuscript. Agustin Blanco provided highly qualified technical assistance for the illustrations 
shown in the paper. Analytical support was provided by the laboratories of the Interdepartmental Research Service (SIDI) from Universidad Autonoma de Madrid. The work has been financed by Projects CGL2008-05813-CO2-02 and 01 as well as by Project CGL2011-25754 (Spanish Ministry of Science and Innovation). We are indebted to General Direction of Historic Heritage (Regional Government of Madrid) for its financial and logistical support. The work is part of the scientific activities of Research Group BSCH UCM-910607.

\section{REFERENCES}

Ahmad, N. (1996) Occurrence and distribution of vertisols. In: Vertisols and Technologies for their Management (Eds N. Ahmad and A. Mermut), pp. 1-41, Dev. Soil Sci., 24, Elsevier, Amsterdam.

Alonso-Zarza, A.M. (2003) Palaeoenvironmental significance of palustrine carbonates and calcretes in the geological record. Earth-Sci. Rev., 60, 261-298.

Alonso-Zarza, A.M. and Calvo, J.P. (2002) Tajo basin. In: The Geology of Spain (Eds W. Gibbons and T. Moreno), pp. 315-320. The Geological Society, London.

Alonso-Zarza, A.M. and Wright, V.P. (2010) Palustrine carbonates. In: Carbonates in Continental Settings. Facies, Environments and Processes (Eds A.M. AlonsoZarza and L.H. Tanner), Elsevier, Dev. Sedimentol., 61, 103-131.

Alonso-Zarza, A.M., Calvo, J.P., Silva, P.G. and Torres, T. (2004) La Cuenca del Tajo. In: Geologia de España (Ed. J.A. Vera), pp. 556-561, Sociedad Geologica de España Instituto Geologico y Minero de España, Madrid.

Anton, M., Salesa, M., Morales, J. and Turner, A. (2004) First known complete skulls of the scimitar-toothed cat Machairodus aphanistus (Felidae, carnivore) from the Spanish Late Miocene site of Batallones-1. J. Vertebrate. Paleontol., 24, 957-969.

Behrensmeyer, A.K. (1991) Terrestrial vertebrate accumulations. In: Taphonomy: Releasing the Data Locked in the Fossil Record (Eds P. Allison and D. Briggs), pp. 291-335 Plenum Press, New York.

Bellanca, A., Calvo, J.P., Censi, P., Neri, R. and Pozo, M. (1992) Recognition of lake-level changes in Miocene lacustrine units, Madrid Basin, Spain. Evidence from facies analysis, isotope geochemistry and clay mineralogy. Sed. Geol., 76, 135-153.

Benito, G., Rico, M., Sanchez-Moya, Y., Sopeña, A., Thornycroft, W.R. and Barriendos, M. (2010) The impact of Holocene climatic variability and land use change on the flood hydrology of the Guadalentin River, southeast Spain. Global Planet. Change, 70, 53-63.

Benson, L., White, L.D. and Rye, R. (1996) Carbonate deposition, Pyramid Lake Subbasin, Nevada: 4. Comparison of the stable isotope values of carbonate deposits (tufas) and the Lahontan lake-level record. Palaeogeogr. Palaeoclimatol. Palaeoecol., 122, 45-76.

Berger, G.W., P'erez-González, A., Carbonell, E., Arsuaga, J.L., Bermúdez de Castro, J.M. and Ku, T.L. (2008) Luminescence chronology of cave sediments at the
Atapuerca paleoanthropological site, Spain. J. Human Evol., 55, 300-311.

Blair, T.C. (1999) Sedimentology of the debris-flowdominated Warm Spring Canyon alluvial fan, Death Valley, California. Sedimentology, 46, 941-965.

Blair, T.C. and McPherson, J.G. (1998) Recent debris-flow processes and resultant form and facies of the Dolomite Alluvial Fan, Owens Valley, California. J. Sed. Res., 68, 800-818.

Bryan, R.B. and Jones, A.A. (1997) The significance of soil piping processes: inventory and prospect. Geomorphology, 20, 209-218.

Bryan, R.B., Yair, A. (Eds) (1982) Badland Geomorphology and Piping. Geobooks, Norwich, 408pp.

Busch, C., Antinuchi, C.D., del Valle, J.C., Kittlein, M.J., Malizia, A.I., Vassallo, A.I. and Zenuto, R.R. (2000) Population ecology of subterranean rodents. In: Life Underground: The Biology of Subterranean Rodents (Eds E.A. Lacey, J.L. Patton and G.N. Cameron), pp. 183-226 Chicago University Press, Chicago.

Bustillo, M.A. and Alonso-Zarza, A.M. (2007) Overlapping of pedogenesis and meteoric diagenesis in distal alluvial and shallow lacustrine deposits in the Miocene Madrid Basin, Spain. Sed. Geol., 198, 255-271.

Bustillo, M.A. and Bustillo, M. (2000) Miocene silcretes in argillaceous playa deposits, Madrid Basin, Spain: petrological and geochemical features. Sedimentology, 47, 1023-1037.

Calvo, J.P. (2004) Rasgos comunes de las cuencas cenozoicas. In: Geologia de España (Ed. J.A. Vera), pp. 584-586, Sociedad Geológica de España - Instituto Geologico y Minero de Espana, Madrid.

Calvo, J.P., Daams, R., Morales, J., Lopez-Martinez, N., Agusti, J., Anadon, P., Armenteros, I., Cabrera, L., Civis, J., Corrochano, A., Diaz-Molina, M., Elizaga, E., Hoyos, M., Martin-Suarez, E., Martinez, J., Moissenet, E., Muñoz, A., P’erez-Garcia, P., P’erez-González, A., Portero, J.M., Robles, F., Santisteban, C., Torres, T., Van der Meulen, A.J., Vera, J.A. and Mein, P. (1993) Up-to-date Spanish continental Neogene synthesis and paleoclimatic interpretation. Rev. Soc. Geol. Esp., 6, 29-40.

Calvo, J.P., Ordoñez, S., Garcia del Cura, M.A., Hoyos, M. and Alonso-Zarza, A.M. (1994) Madrid Basin (Miocene). In: A Global Geological Record of Lake Basins (Eds E. Gierlowski-Kordesch and K. Kelts), pp. 303-305. Cambridge University Press, Cambridge.

Calvo, J.P., Jones, B.F., Bustillo, M., Fort, R., Alonso-Zarza, A.M. and Kendall, C. (1995a) Sedimentology and geochemistry of carbonates from lacustrine sequences in the Madrid Basin, central Spain). Chem. Geol., 123, 173191.

Calvo, J.P., Pozo, M. and Jones, B.F. (1995b) Preliminary report of seepage mound occurrences in Spain. Comparison with carbonate mounds from the Amargosa Desert, western USA. Geogaceta, 18, 67-70.

Cañaveras, J.C., Calvo, J.P., Hoyos, M. and Ordoñez, S. (1996) Paleomorphologic features of an intra-Vallesian paleokarst, Tertiary Madrid Basin. Significance of paleokarstic surfaces in continental basin analysis. In: Tertiary Iberian Basins (Eds P.F. Friend and C.J. Dabrio), pp. 278-284. Cambridge University Press, Cambridge, UK.

De Vicente, G., Cloething, S., Van Wees, J.D. and Cunha, P.P. (2011) Tectonic classification of Cenozoic Iberian foreland basins. Tectonophysics, 502, 38-61. 
Deocampo, D.M. (2010) The geochemistry of continental carbonates. In: Carbonates in Continental Settings. Geochemistry, Diagenesis and Applications (Eds A.M. Alonso-Zarza and L.H. Tanner), Elsevier, Dev. Sedimentol., 62, 1-59.

Domingo, M.S., Domingo, L., Sanchez, I.R., Alberdi, M.T., Azanza, B. and Morales, J. (2011) New insights on the taphonomy of the exceptional mammalian fossil sites of Cerro de los Batallones (Late Miocene, Spain) based on rare earth element geochemistry. Palaios, 26, 55-65.

Floridia, G. (1941) Un particolare fenomeno seudocarsico manifestato da algune argile. Bolletino della Societa dei Sciencia Naturale ed Economiche di Palermo, 23, 10-19.

Galan, E. and Pozo, M. (2011) Palygorskite and sepiolite deposits in continental environments. Description, genetic patterns and sedimentary settings. In: Developments in Palygorskite - Sepiolite Research. A New Outlook on these Nanomaterials (Eds E. Galan and A. Singer), Dev. Clay Sci., 3, 125-173. Elsevier, Amsterdam.

Genise, J.F. and Farina, J.L. (2012) Ants and xenarthrans involved in a quaternary food web from Argentina as reflected by their fossil nests and palaeocaves. Lethaia, 45, 411-422.

Halliday, W.R. (2007) Pseudokarst in the 21st century. J. Cave Karst Stud., 69, 103-113.

Jones, B. and Renaut, R.W. (2010) Calcareous spring deposits in continental settings. In: Carbonates in Continental Settings. Facies, Environments and Processes (Eds A.M. Alonso-Zarza and L.H. Tanner), Elsevier, Dev. Sedimentol., 61, 177-224.

Kaufman, O., Deceuster, J. and Quinif, Y. (2012) An electrical resistivity imaging-based strategy to enable site-scale planning over covered palaeokarst features in the Tournaisis area (Belgium). Eng. Geol., 133-134, 49-65.

Laury, R.L. (1980) Paleoenvironment of a late Quaternary mammoth-bearing sinkhole deposit, Hot Springs, South Dakota. Geol. Soc. Amer. Bull., 91, 465-475.

Lindholm, R.C. and Finkelman, R.B. (1972) Calcite staining: semiquantitative determination of ferrous iron. J. Sed. Petrol., 42, 239-245.

Lopez-Antoñanzas, R., Peláez-Campomanes, P., AlvarezSierra, M.A. and Garcia-Paredes, I. (2010) New species of Hispanomys (Rodentia, Cricetodontinae) from the Upper Miocene of Batallones (Madrid, Spain). Zool. J. Linnean Soc., 160, 725-747.

Morales, J., Capitan, J., Calvo, J.P. and Sesé, C. (1992) Nuevo yacimiento de vertebrados del Mioceno Superior al Sur de Madrid (Cerro de Batallones, Torrejon de Velasco). Geogaceta, 12, 77-80.

Morales, J., Nieto, M., Amezua, L., Fraile, S., Gomez, E., Herraez, E., Pelaez-Campomanes, P., Salesa, M.J., Sanchez, I.M. and Soria, D. (Eds) (2000) Patrimonio Paleontologico de la Comunidad de Madrid, Monograph 6. Arqueologia, Paleontologia y Etnografia, Consejeria de Cultura, Comunidad de, Madrid, 371 pp.

Morales, J., Alcala, L., Ảlvarez-Sierra, M.A., Anton, M., Azanza, B., Calvo, J.P., Carrasco, P., Fraile, S., GarciaParedes, I., Gomez, E., Hernández-Fernández, M., Merino, L., van der Meulen, J.A., Martin-Escorza, C., Montoya, P., Nieto, M., Peigne, S., P'erez, B., Pelaez-Campomanes, P., Pozo, M., Quiralte, V., Salesa, M.J., Sanchez, I.M., Sanchez-Marco, A., Silva, P.G., Soria, D. and Turner, A. (2004) Paleontologia del sistema de yacimientos de mamiferos miocenos del Cerro de los Batallones, Cuenca de Madrid. Geogaceta, 35, 139-142.
Morales, J., Pozo, M., Silva, P.G., Domingo, M.S., LopezAntoñanzas, R., Alvarez-Sierra, M.A., Anton, M., Martin-Escorza, C., Quiralte, V., Salesa, M.J., Sanchez, I.M., Azanza, B., Calvo, J.P., Carrasco, P., GarciaParedes, I., Knoll, F., Hernandez-Fernández, M., van der Hoek Ostende, L., Merino, L., van der Meulen, J.A., Montoya, P., Peigne, S., Pelaez-Campomanes, P., Sanchez-Marco, A., Turner, A., Abella, J., Alcalde, G.M., Andres, M., De Miguel, D., Cantalapiedra, J.L., Fraile, S., Garcia Yelo, B.A., Gomez Cano, A.R., Lopez Guerrero, P., Oliver Perez, A. and Siliceo, G. (2008) El sistema de yacimientos de mamiferos miocenos del Cerro de los Batallones, Cuenca de Madrid: Estado actual y perspectivas. Paleontol. Nova SEPAZ, 8, 41-117.

Muñoz-Duran, J. and Van Valkenburgh, B. (2006) The Rancholabrean record of Carnivora: taphonomic effect of body size, habitat breadth, and the preservation potential of caves. Palaios, 21, 424-430.

Ord’õnez, S. and Garća del Cura, M.A. (1994) Deposition and diagenesis of sodium-calcium sulphate salts in the Tertiary saline lakes of the Madrid Basin, Spain. In: Sedimentology and Geochemistry of Modern and Ancient Saline Lakes (Eds R.W. Renaut and W.M. Last), SEPM Spec. Publ., 50, 229-238.

Parker, G.G. (1963) Piping, a geomorphic agent in landform development of the drylands. Int. Assoc. Sci. Hydrol. Publ., 65, 103-113.

Paton, T.R. (1974) Origin and terminology for gilgai in Australia. Geoderma, 11, 221-242.

Paz, J.D.S. and Rossetti, D.F. (2006) Paleohydrology of an Upper Aptian lacustrine system from northeastern Brazil: Integration of facies and isotopic geochemistry. Palaeogeogr. Palaeoclimatol. Palaeoecol., 241, 247-266.

Peigne, S., Salesa, M.J., Anton, M. and Morales, J. (2008) A new Amphicyonine (Carnivora: Amphicyonidae) from the Upper Miocene of Batallones-1, Madrid, Spain. Palaeontology, 51, 943-965.

Platt, N.H. and Wright, V.P. (1992) Palustrine carbonates at the Florida Everglades: Towards an exposure index for the fresh-water environment. J. Sed. Petrol., 62, 1058-1071.

Pozo, M., Calvo, J.P., Silva, P.G., Morales, J. and PeláezCampomanes, P. (2004) Geologia del sistema de yacimientos de mamiferos miocenos del Cerro de los Batallones, Cuenca de Madrid. Geogaceta, 35, 143-146.

Reed, E.H. (2006) In situ taphonomic investigation of Pleistocene large mammal bone deposits from The Ossuaries, Victoria Fossil Cave, Naracoorte, South Australia. Helatictite, 39, 5-15.

Rodriguez-Aranda, J.P., Calvo, J.P. and Sanz-Montero, M.E. (2002) Lower Miocene gypsum palaeokarst in the Madrid Basin (central Spain): dissolution diagenesis, morphological relics and karst end-products. Sedimentology, 49, 1385-1400.

Salesa, M.J., Anton, M., Turner, A. and Morales, J. (2009) Functional anatomy of the forelimb in Promegantereon agygia (Felidae, Machairodontinae, Smilodontini) from the Late Miocene of Spain and the origins of the sabre-toothed felid model. J. Anatomy, 216, 381-396.

Sanchez, I.M., Domingo, M.S. and Morales, J. (2009) New data on the Moschidae (Mammalia, Ruminantia) from the upper Miocene of Spain (MN 10-MN 11). J. Vertebr. Paleontol., 29, 567-575. 
Schultz, L.G. (1964) Quantitative interpretation of mineralogical composition from X-ray and chemical data for the Pierre Shale. Geol. Surv. Prof. Paper 391-C, 31.

Silva, P.G., Goy, J.L. and Zazo, C. (1988) Neotectonica del sector centro-meridional de la Cuenca de Madrid. Estud. Geol., 44, 415-427.

Silva, P.G., Lopez Recio, M., Cuartero, F., Baena, J., Tapias, F., Manzano, I., Martin, D., Morin, J. and Roquero, E. (2012) Geomorphological setting and main technological features of new Middle and Upper Pleistocene sites in the Lower Manzanares River Valley (Madrid, Spain). Estud. Geol., 68, 57-89, doi:10.3989/egeol.40338.134.

Simms, M.J. (1994) Emplacement and preservation of vertebrates in caves and fissures. Zool. J. Linnean Soc., 112, 261-283.

Talbot, M.R. (1990) A review of the palaeohydrological interpretation of carbon and oxygen isotopic ratios in primary lacustrine carbonates. Chem. Geol. Isot. Geosci. Sect., 80, 261-279.
Thiry, M. (1997) Continental silicifications: a review. In: Soils and Sediments, Mineralogy and Geochemistry (Eds H. Paquet and N. Clauer), pp. 191-221, Springer, Berlin, Heidelberg.

Tucker, M.E. (2001) Sedimentary Petrology, 3rd ed. Blackwell Science, Oxford, 262 pp.

Van der Marel, H.W. (1966) Quantitative analysis of clay minerals and their admixtures. Contrib. Miner. Petrol., 12, 96-138.

Van Schoor, M. (2004) Detection of sinkholes using 2D electrical resistivity imaging. J. Appl. Geophys., 50, 393-399.

White, W.B. (2007) Cave sediments and paleoclimate. J. Cave Karst Stud., 69, 76-93.

Zhu, T.X., Luk, S.H. and Cai, Q.G. (2002) Tunnel erosion and sediment production in the hilly loess region. North China. J. Hydrol., 257, 78-90. 